\title{
Konkurencyjność sektora rolno-spożywczego w Polsce na tle uwarunkowań makroekonomicznych
}

\begin{abstract}
Competitiveness of the agri-food sector in Poland in light of macroeconomic determinants: The aim of this study is to assess the competitiveness of the Polish agri-food sector for 2004-2017, taking into account its most important sections. It begins with the discussion about the macroeconomic determinants of the competitiveness of the agri-food sector, i.e. the most important external (international) and internal (domestic) factors affecting its competitiveness. Next, the growth of foreign trade in Polish agri-food products is described, both in total volumes and the results in particular groups. The competitiveness of the Polish agri-food sector and its most important sections was assessed on the basis of two quantitative indicators: the trade coverage index (TC) and the revealed comparative advantage (RCA) in exports. The analysis shows that in 2004-2017 agri-food trade in Poland was growing dynamically and the indicators significantly improved in most sections. The authors claim that the improvement of the competitiveness of the agri-food sector in Poland benefited from favourable macroeconomic determinants, both international and domestic ones.
\end{abstract}

Słowa kluczowe: konkurencyjność gospodarki narodowej, rolnictwo w Polsce, sektor rolno-spożywczy w Polsce, handel międzynarodowy produktami rolnymi

Keywords: competitiveness of national economy, agriculture in Poland, agri-food sector in Poland, international trade in agricultural products

* Doktor nauk ekonomicznych, adiunkt, kierownik Zakładu Ekonomiki Przemysłu Spożywczego, Instytut Ekonomiki Rolnictwa i Gospodarki Żywnościowej - Państwowy Instytut Badawczy; e-mail: Iwona.Szczepaniak@ierigz.waw.pl.

** Doktor nauk ekonomicznych, adiunkt w Zakładzie Ekonomiki Przemysłu Spożywczego, Instytut Ekonomiki Rolnictwa i Gospodarki Żywnościowej - Państwowy Instytut Badawczy; e-mail: Lukasz.Ambroziak@ierigz.waw.pl.

*** Doktor nauk ekonomicznych, adiunkt w Zakładzie Ekonomiki Przemysłu Spożywczego, Instytut Ekonomiki Rolnictwa i Gospodarki Żywnościowej - Państwowy Instytut Badawczy; e-mail: Katarzyna.Kosior@ierigz.waw.pl. 


\section{Wstęp}

Złożoność i wielowymiarowość zjawiska konkurencyjności powoduje, że brak jest jednoznacznie wypracowanych i powszechnie akceptowanych jego definicji. Z bardziej ogólnych definicji konkurencyjności można przytoczyć definicję M.J. Stankiewicza. Autor ten opisuje konkurencyjność jako zdolność do sprawnego realizowania celów na rynkowej arenie konkurencji, przy czym przez sprawność rozumie skuteczność, korzystność i ekonomiczność. Wyróżnia on dwa rodzaje konkurencyjności, tj. operacyjną (dotyczącą wnętrza danego podmiotu) i systemową (dotyczącą szerokiego obszaru zachowań podmiotu) ${ }^{1}$. Jak pisze z kolei J. Misala, konkurencyjność jest pojęciem, które pozwala oceniać działania podmiotów gospodarczych uczestniczących w walce konkurencyjnej z punktu widzenia osiąganych wyników. Mechanizmem umożliwiającym ocenę tych wyników jest zaś rynek, na którym dokonuje się selekcja podmiotów pod względem poziomu ich konkurencyjności².

Konkurencyjność podmiotów działających na rynku w warunkach konkurencji jest klasyfikowana według wielu kryteriów. Jednym z nich jest zasięg konkurowania. W takim ujęciu można mówić o konkurencyjności w skali krajowej lub międzynarodowej. W literaturze przedmiotu konkurencyjność częściej odnoszona jest jednak do rynku zagranicznego lub globalnego, chociaż pojawia się też pogląd, że o sukcesie na tych rynkach decyduje wygrana walka konkurencyjna na rynku krajowym. Takie podejście prezentuje powszechnie cytowana definicja OECD, która brzmi: konkurencyjność oznacza zarówno zdolność firm, przemystów, regionów, narodów lub ponadnarodowych ugrupowań do sprostania międzynarodowej konkurencji, jak i do zapewniania relatywnie wysokiej stopy zwrotu od zastosowanych czynników produkcji i relatywnie wysokiego zatrudnienia na trwałych podstawach ${ }^{3}$. Literatura przedmiotu i wskaźniki przyjęte do oceny konkurencyjności na poziomie sektorowym wskazują jednak, że konkurencyjność na tym poziomie najczęściej oceniana jest przez pryzmat wyników handlu zagranicznego poszczególnymi produktami lub ich grupami oraz pozycji produktów sektora na rynku światowym czy na rynkach regionalnych ${ }^{4}$. W literaturze często można też znaleźć opinie, że rynek zagraniczny jest trudniejszy

1 M.J. Stankiewicz, Konkurencyjność przedsiębiorstwa. Budowanie konkurencyjności przedsiębiorstwa w warunkach globalizacji, Wydawnictwo TNOiK „Dom Organizatora”, Toruń 2005, s. 36-38.

2 J. Misala, Międzynarodowa zdolność konkurencyjna i międzynarodowa konkurencyjność gospodarki narodowej. Podstawy teoretyczne, Politechnika Radomska, Radom 2007.

3 Industrial Structure Statistics 1994, OECD, Paris 1996 [za:] M.J. Stankiewicz, Konkurencyjność, op. cit., s. 36.

${ }^{4}$ M.in. J. Misala, Międzynarodowa zdolność, op. cit., s. 14-45; idem, Międzynarodowa konkurencyjność gospodarki narodowej, PWE, Warszawa 2011, s. 63-85; K. Pawlak, W. Poczta, Międzynarodowy handel rolny, PWE, Warszawa 2011, s. 41-77. 
dla producentów niż rynek krajowy, a więc rzeczywisty poziom konkurencyjności sektora można stwierdzić tylko na podstawie wyników osiąganych przez producentów na rynku międzynarodowym ${ }^{5}$. Podejście to jest wykorzystywane także przy ocenach konkurencyjności sektora rolno-spożywczego. Zdaniem K. Pawlak: $w$ analizach konkurencyjności sektora rolno-spożywczego szczególnie przydatne wydaje się podejście związane z nurtem teorii handlu zagranicznego, odwołujące się do konkurencyjności jako zdolności skutecznej sprzedaży wytwarzanych produktów na rynkach międzynarodowych, a tym samym utrzymania lub powiększania udziałów rynkowych ${ }^{6}$.

Zintensyfikowanie w ostatnich latach badań dotyczących międzynarodowej konkurencyjności ma również ścisły związek z procesami integracyjnymi i globalizacyjnymi na świecie. Procesy te, występujące z różnym natężeniem w wielu obszarach życia społecznego i gospodarczego, wywierają bowiem znaczny wpływ na funkcjonowanie i perspektywy rozwoju przedsiębiorstw $\mathrm{i}$ tworzonych przez nie sektorów. Uwzględniając to, w prowadzonych w Instytucie Ekonomiki Rolnictwa i Gospodarki Żywnościowej - Państwowym Instytucie Badawczym (IERiGŻ-PIB) badaniach konkurencyjności polskiego sektora rolno-spożywczego ${ }^{7}$ podkreśla się, że producenci żywności w Polsce powinni być konkurencyjni w porównaniu z przedsiębiorstwami funkcjonującymi na wspólnym rynku Unii Europejskiej (UE), jak i na rynkach krajów spoza UE, a także konkurencyjni wobec zagranicznych podmiotów obecnych na rynku krajowym. Takie podejście jest jednoznaczne ze stwierdzeniem, że konkurencyjność sektora to zdolność do sprostania konkurencji międzynarodowej, a więc realizowania dużego eksportu, ale także zdolność do utrzymania wysokiego poziomu i tempa rozwoju rynku wewnętrznego. Skutkuje to przyjęciem na użytek niniejszych badań definicji konkurencyjności polskiego sektora rolno-spożywczego, jako zdolności do lokowania się krajowych producentów żywności na rynkach zagranicznych oraz zdolności rozwijania eksportu.

Celem badań jest ocena konkurencyjności polskiego sektora rolno-spożywczego (w tym jego najważniejszych działów) na rynku światowym. Analizę tę rozpoczęto od omówienia uwarunkowań makroekonomicznych konkurencyjności sektora rolno-spożywczego w Polsce, tj. najważniejszych czynników zewnętrznych (międzynarodowych) i wewnętrznych (krajowych) oddziałujących na konkurencyjność polskiej gospodarki żywnościowej. W dalszej kolejności przedstawiono rozwój handlu zagranicznego produktami rolno-spożywczymi

${ }^{5}$ M. Olczyk, Konkurencyjność. Teoria i praktyka, CeDeWu.PL, Warszawa 2008, s. 53-54.

${ }^{6}$ K. Pawlak, Międzynarodowa zdolność konkurencyjna sektora rolno-spożywczego krajów Unii Europejskiej, seria „Rozprawy Naukowe, Uniwersytet Przyrodniczy w Poznaniu”, nr 448, Poznań 2013, s. 32-36.

7 I. Szczepaniak, System „konkurencyjnośc” - wybrane aspekty teoretyczne i empiryczne [w:] Monitoring i ocena konkurencyjności polskich producentów żywności (5) Synteza, red. I. Szczepaniak, seria „Program Wieloletni 2010-2014”, nr 115, IERiGŻ-PIB, Warszawa 2014, s. $10-11$. 
Polski - zarówno handlu ogółem, jak i handlu poszczególnymi grupami produktów. Pozycję konkurencyjną Polski w handlu produktami rolno-spożywczymi oceniono na podstawie dwóch ilościowych wskaźników konkurencyjności, tj. wskaźnika pokrycia importu eksportem (TC) oraz wskaźnika ujawnionych przewag komparatywnych w eksporcie (RCA). Analizą porównawczą objęto lata 2004-2017, czyli cały okres członkostwa Polski w UE. Artykuł zakończono podsumowaniem i wnioskami.

Badanie konkurencyjności przeprowadzono na podstawie danych handlowych pochodzących z bazy World Integrated Trade Solution (WITS-Comtrade), wyrażonych w dolarach US. Pod pojęciem produktów rolno-spożywczych rozumiano działy 01-24 Zharmonizowanego Systemu Oznaczania i Kodowania Towarów (HS, Harmonized System).

\section{Uwarunkowania makroekonomiczne konkurencyjności sektora rolno-spożywczego w Polsce}

Konkurencyjność sektora rolno-spożywczego w Polsce kształtowana jest przez wiele czynników i zjawisk społeczno-gospodarczych, które ulokowane są i mają swoje źródło w procesach zachodzących zarówno w kraju, jak i w środowisku międzynarodowym. Uwarunkowania makroekonomiczne konkurencyjności można zatem podzielić na dwie główne kategorie - na uwarunkowania określane przez czynniki zewnętrzne (międzynarodowe) oraz uwarunkowania determinowane przez czynniki wewnętrzne (krajowe) ${ }^{8}$. Zaznaczyć należy jednak, że ze względu na postępujący proces globalizacji oraz rosnący stopień integracji gospodarek narodowych czynniki zewnętrzne i wewnętrzne oddziałujące na konkurencyjność często nachodzą na siebie. Trzeba też dodać, że nie wszystkie $\mathrm{z}$ nich są łatwe do obserwacji i mierzenia9 .

W niniejszym opracowaniu uwzględnione zostały najważniejsze uwarunkowania międzynarodowe i krajowe konkurencyjności polskiej gospodarki żyw-

${ }^{8}$ W literaturze przedmiotu znaleźć można wiele ujęć i klasyfikacji czynników oddziałujących na konkurencyjność. Przyjęty podział na czynniki zewnętrzne (międzynarodowe) i wewnętrzne (krajowe) jest jednym z najbardziej ogólnych i równocześnie najbardziej pojemnych analitycznie podziałów stosowanych w ocenach i badaniach międzynarodowej konkurencyjności gospodarek narodowych. Warto zaznaczyć, że różne podejścia do badań konkurencyjności oraz różne klasyfikacje czynników oddziałujących na konkurencyjność wynikają nie tylko z różnych perspektyw badawczych przyjmowanych w analizach, ale także $\mathrm{z}$ różnych interpretacji i definicji samego pojęcia konkurencyjności. Więcej na temat definicji, mierników i determinant konkurencyjności zob. m.in. T. Siudek, K. Drabarczyk, Teoretyczne i aplikacyjne aspekty konkurencyjności - przegląd literatury, „Zeszyty Naukowe Szkoły Głównej Gospodarstwa Wiejskiego. Ekonomika i Organizacja Gospodarki Żywnościowej” 2015, nr 112, s. 137-153.

9 M. Peneder, Competitiveness and industrial policy: from rationalities of failure towards the ability to evolve, „Cambridge Journal of Economics” 2017, Vol. 41, No. 3, s. 829-858. 
nościowej. Wśród kluczowych uwarunkowań międzynarodowych wymienić należy: a) zmiany zapotrzebowania na żywność w skali światowej i regionalnej wynikające ze zmian demograficznych i społeczno-gospodarczych w poszczególnych krajach i regionach świata; b) rozwój wielostronnego systemu handlowego, w tym stopień liberalizacji światowego handlu produktami rolno-spożywczymi; c) dostęp do wspólnego rynku Unii Europejskiej i funduszy strukturalnych UE oraz wsparcie sektora rolnego z unijnego budżetu wspólnej polityki rolnej (WPR). W odniesieniu do czynników krajowych na perspektywy rozwoju i utrzymania konkurencyjności w największym stopniu oraz w sposób bezpośredni oddziałują: a) poziom i tempo rozwoju gospodarki narodowej oraz b) stabilność makroekonomiczna kraju. Uwzględnione zostały zatem takie wskaźniki, jak: wzrost produktu krajowego brutto (PKB), poziom inflacji, stopa bezrobocia, poziom deficytu budżetowego i długu publicznego, PKB na jednego mieszkańca, a także kurs wymiany walut (złotego do euro). Zestawiono także wyniki w zakresie krajowej produktywności pracy i jednostkowych kosztów pracy ze względu na rolę, jaką czynniki te odgrywają w kształtowaniu przewag konkurencyjnych w handlu zagranicznym.

\section{Popyt na żywność w skali światowej i regionalnej}

W ciągu ostatnich pięćdziesięciu lat światowy popyt na żywność zwiększył się ponadtrzykrotnie ${ }^{10}$. Przyczynił się do tego wzrost liczby ludności świata (z 3 do ponad 7 mld osób) oraz wzrost popytu per capita na żywność, wynikający z rosnącego poziomu zamożności i wyższych standardów życia społeczeństw poszczególnych krajów ${ }^{11}$. W ciągu pierwszych kilkunastu lat obecnego stulecia światowy popyt na żywność rósł w tempie ok. 2\% rocznie - między 2000 a 2013 rokiem zwiększył się z $3745 \mathrm{mln}$ ton do $4877 \mathrm{mln}$ ton (o 30,2\%) ${ }^{12}$. Źródłem wzrostu popytu na żywność były przede wszystkim kraje rozwijające się. W krajach rozwiniętych popyt na żywność pozostawał stabilny ${ }^{13}$. Zmianom poziomu zapotrzebowania na żywność na świecie towarzyszyły również zmiany struktury globalnego popytu na żywność. Zwiększone spożycie objęło wszystkie podstawowe grupy artykułów żywnościowych z wyjątkiem zbóż. Szczególnie wysoka dynamika wzrostu konsumpcji dotyczyła owoców i warzyw oraz produktów pochodzenia zwierzęcego, w tym zwłaszcza mięsa i mleka ${ }^{14}$.

${ }_{10}$ B.L. Bodirsky i in., Global Food Demand Scenarios for the $21^{\text {st }}$ Century, „PLOS ONE” 2015, nr 10(11).

${ }^{11}$ Ibidem.

12 A. Mikuła, Demograficzne uwarunkowania światowego i krajowego popytu na żywność w latach 2000-2015 [w:] Ewolucja światowego i krajowego popytu na żywność w kontekście zmian demograficznych i bezpieczeństwa żywnościowego, red. K. Świetlik, seria „Monografie Programu Wieloletniego 2015-2019”, nr 65, IERiGŻ-PIB, Warszawa 2017, s. 39.

${ }_{13}$ Ibidem.

${ }^{14}$ Ibidem, s. 48. 
Zapotrzebowanie na żywność nadal będzie wzrastać w związku z prognozowanym wzrostem liczby ludności świata. Oczekuje się, że w 2050 r. liczba mieszkańców globu zwiększy się do ponad 9 mld, co - w scenariuszu zakładającym umiarkowany wzrost gospodarczy - doprowadzi do wzrostu popytu na żywność o ok. 50\% w porównaniu z rokiem $2013^{15}$. Perspektywy zaspokojenia rosnącego popytu na żywność są niepewne, zwłaszcza w związku z negatywnym wpływem zmian klimatycznych na rolnictwo i produkcję żywności w różnych krajach. Prognozowany wzrost liczby ludności skoncentrowany będzie w krajach rozwijających się i w dwóch regionach świata - Afryce i Azji Południowej ${ }^{16}$. Pod koniec obecnego stulecia tylko na tych dwóch kontynentach żyć może nieco ponad $80 \%$ ludności świata ( 9 z 11 mld osób, które w 2100 r. zamieszkiwać będą Ziemię $)^{17}$. Pomimo rosnącej w ostatnich latach konsumpcji, poziom wyżywienia w krajach rozwijających się wciąż jest dużo niższy niż w krajach rozwiniętych, również pod względem udziału żywności pochodzenia zwierzęcego w wartości energetycznej codziennej racji pokarmowej. Wobec poprawy sytuacji dochodowej społeczeństw krajów rozwijających się, a także w związku z rosnącą popularnością modeli konsumpcji rozpowszechnionych w krajach rozwiniętych oczekuje się, że w kolejnych dekadach nastąpi zarówno dynamiczny wzrost zapotrzebowania na żywność, jak i dalszy wzrost udziału produktów zwierzęcych w strukturze światowego popytu na żywność ${ }^{18}$. Jedynym kontynentem, gdzie populacja i zapotrzebowanie na żywność zmniejszy się, będzie Europa. Zgodnie z prognozami w $2050 \mathrm{r}$. Europę zamieszkiwać będzie $707 \mathrm{mln}$ osób, o 4,3\% mniej niż w 2015 r. ${ }^{19}$. Również w Polsce liczba ludności będzie spadać - Organizacja Narodów Zjednoczonych prognozuje, że do połowy obecnego stulecia populacja naszego kraju zmaleje do ok. 33 mln osób ${ }^{20}$.

Zmiany demograficzne obserwowane w ostatnim okresie i prognozowane na kolejne dekady, a także zmiany struktury popytu na żywność, wpływały i będą wpływać na perspektywy rozwoju polskiego sektora żywnościowego. Już pod koniec ubiegłej dekady, wobec silnej redukcji tempa wzrostu wartości spożycia żywności w Polsce, coraz większego znaczenia dla polskich producentów żywności zaczęła nabierać orientacja eksportowa. Choć w latach 2000-2008 spożycie

15 The Future of Food and Agriculture. Trends and Challenges, Food and Agriculture Organization of the United Nations, Rome 2017.

16 Ibidem, s. 3.

17 Ibidem.

18 B.L. Bodirsky i in., Global Food Demand Scenarios, op. cit.

19 World Population Prospects. The 2015 Revision. Key Findings and Advance Tables, United Nations, New York 2015.

${ }^{20}$ Ibidem. Prognozy GUS i Eurostatu wskazują na nieco mniejszy spadek liczby ludności w Polsce do 2050 r. (do ok. $34 \mathrm{mln}$ ), jednak procentowo nadal będzie to spadek wyraźnie większy niż ten prognozowany dla całej Europy (10,5\% wobec 4,3\%). Zob. więcej. A. Mikuła, Demograficzne uwarunkowania, op. cit., s. 32. 
żywności i napojów bezalkoholowych w Polsce zwiększało się w tempie ok. 1,9\% rocznie, to już w latach 2009-2013 zmniejszało się o ok. 1,1\% rocznie ${ }^{21}$. Rozwój sektora rolno-spożywczego, w tym poprawę wyników sprzedaży, umożliwiał przede wszystkim dostęp do wciąż chłonnych rynków krajów członkowskich UE. Równocześnie jednak globalne i regionalne uwarunkowania rozwoju popytu na żywność wzmacniały znaczenie strategii dywersyfikowania kierunków eksportu poza rynki krajów unijnych i krajów sąsiednich. W ostatnich latach zaobserwować można było rosnącą aktywność polskich producentów żywności na rynkach krajów trzecich - w Ameryce Północnej, Afryce, Azji i na Bliskim Wschodzie.

Podsumowując, trzeba stwierdzić, że uwarunkowania zewnętrzne związane z rosnącym popytem na żywność w skali światowej i regionalnej sprzyjały w ostatnich latach rozwojowi polskiego sektora rolno-spożywczego. W związku z prognozowanymi zmianami liczby ludności (konsumentów) na świecie można jednak oczekiwać, że zmieniać się będzie znaczenie i rola poszczególnych rynków zbytu ${ }^{22}$. Nie musi to oznaczać pogorszenia konkurencyjności polskiego eksportu rolno-spożywczego. Ta bowiem w dużej mierze zależeć będzie od stopnia liberalizacji światowego handlu rolno-spożywczego, w tym od dostępu do rynków, na których oczekiwane są dalsze wzrosty popytu na żywność.

\section{Wielostronny system handlowy WTO i stopień liberalizacji światowego handlu rolno-spożywczego}

Rolnictwo przez długi czas znajdowało się poza systemem wielostronnych negocjacji w sprawie liberalizacji światowego handlu. Dopiero w 1995 r., wraz z ustanowieniem Światowej Organizacji Handlu (WTO), państwa-strony umowy GATT (General Agreement on Tariffs and Trade), finalizując negocjacje w ramach Rundy Urugwajskiej, przyjęły porozumienie w sprawie rolnictwa (Uruguay Round Agreement on Agriculture, URAA). Porozumienie URAA określiło reguły i zasady obowiązujące $\mathrm{w}$ światowym handlu rolnym, $\mathrm{w}$ tym również zobowiązania stron do ograniczenia poziomu wsparcia sektorów rolnych oraz do stopniowej liberalizacji wzajemnej wymiany handlowej produktami rolno-spożywczymi.

${ }^{21}$ I. Szczepaniak, Uwarunkowania zewnętrzne konkurencyjności polskich producentów żywności [w:] Konkurencyjność polskich producentów żywności i jej determinanty (1), red. I. Szczepaniak, seria „Monografie Programu Wieloletniego 2015-2019”, nr 11, IERiGŻ-PIB, Warszawa 2015, s. 57.

${ }^{22}$ Rynkami nierozwojowymi, ze względu na stosunkowo wysoki stopień ich nasycenia, będą m.in. rynki krajów UE. Komisja Europejska oczekuje, że $90 \%$ dodatkowego popytu na żywność w ciągu kolejnych 10-15 lat będzie generowane poza Europą. Zob. Impacts of EU trade agreements on the agricultural sector, report prepared for the European Commission, Directorate-General for Agriculture and Rural Development, by A/S Copenhagen Economics, December 2016, https://ec.europa.eu/agriculture/sites/agriculture/files/external-studies/2016-bilateral-trade-agreements/final-report_en.pdf, s. 32. 
Rosnący popyt na żywność, w połączeniu ze wzrostem gospodarczym na świecie i stopniową redukcją stawek celnych, przyczyniły się do dynamicznego rozwoju handlu rolnego w ostatnim okresie. Między rokiem 1995 a 2014 światowy handel produktami rolno-spożywczymi w ujęciu nominalnym (bez uwzględnienia inflacji) zwiększył się ponadtrzykrotnie, w ujęciu realnym (z uwzględnieniem inflacji) niemal dwukrotnie ${ }^{23}$. Mimo obserwowanego wzrostu skala zakłóceń w handlu rolnym pozostawała wysoka. Dla tylko największych gospodarek średni poziom stawek celnych stosowanych w imporcie produktów rolno-spożywczych wynosił 15-22\%, stawek związanych (maksymalny dopuszczalny przez WTO poziom ochrony celnej) - 46\% ${ }^{24}$. Istotnym źródłem zakłóceń były również subsydia rolnicze oraz rosnący poziom barier pozataryfowych ${ }^{25}$. Rozwijane w poprzednich dekadach systemy wsparcia producentów rolnych przyczyniły się do wyraźnej dominacji państw najbogatszych w handlu produktami rolno-spożywczymi. Obecnie łącznie na Unię Europejską (uwzględniając handel wewnątrzunijny) i Stany Zjednoczone przypada niemal połowa wartości globalnego handlu produktami rolno-spożywczymi - 48,1\% wartości eksportu i 46,6\% wartości importu ${ }^{26}$.

Nierówny podział korzyści wynikających z rozwoju handlu rolnego miała rozwiązać kolejna runda negocjacji między członkami WTO, zapoczątkowana w 2001 r. w Ad-Dausze. Jednak ze względu na duże rozbieżności poglądów, stanowisk i oczekiwań państw rozwiniętych i państw rozwijających się nie zdołano dotąd dojść do porozumienia. Podstawową przyczyną braku porozumienia pozostają różnice zdań w odniesieniu do dopuszczalnych form i poziomów subsydiowania sektorów rolnych. Podczas gdy w krajach rozwiniętych od czasu przyjęcia porozumienia URAA wielkość wsparcia dla sektora rolnego stopniowo spada (bądź utrzymuje się na niezmienionym poziomie), w krajach rozwijających się (głównie w gospodarkach wschodzących) poziom subsydiowania rolnictwa sukcesywnie wzrasta, również w związku ze stosowaniem instrumentów zniekształcających handel międzynarodowy, takich jak wsparcie cen rolnych czy dopłaty do środków produkcji ${ }^{27}$. Wobec utrzymującego się od końca ubiegłej dekady impasu w negocjacjach, w grudniu 2015 r. w Nairobi państwa człon-

23 S. Zahniser, J. Beckman, K.E.R. Heerman, World Agricultural Trade Experiences Sizable Growth but Still Faces Barriers, International Markets \& U.S. Trade, February 05, 2018.

24 Ibidem.

25 J. Beckman, J. Dyck, K.E.R. Heerman, The Global Landscape of Agricultural Trade, 1995-2014, EIB-181, U.S. Department of Agriculture, Economic Research Service, November 2017.

26 K. Kosior, Wpływ uwarunkowań makroekonomicznych, politycznych i społecznych na konkurencyjność sektora żywnościowego w Polsce w kontekście procesów globalnych [w:] Konkurencyjność polskich producentów żywności i jej determinanty (3), red. I. Szczepaniak, seria „Monografie Programu Wieloletniego 2015-2019”, nr 67, IERiGŻ-PIB, Warszawa 2017, s. 17.

27 J. Beckman i in., The Global Landscape of Agricultural Trade, op. cit. 
kowskie WTO, w trakcie X konferencji ministerialnej, zgodziły się, że celem nie będzie dążenie do porozumienia, które obejmie wszystkie państwa członkowskie. Zadeklarowano w zamian dążenie do liberalizowania handlu rolnego w ramach porozumień obejmujących mniejszą liczbę państw członkowskich $\mathrm{WTO}^{28}$. Decyzja ta oznacza, że przyjęcie nowego wielostronnego porozumienia w sprawie rolnictwa, w tym wspólnej dyscypliny dla krajowych systemów wsparcia dla rolnictwa, nie będzie w najbliższej przyszłości możliwe ${ }^{29}$. Kryzys systemu wielostronnego WTO potwierdziła również ostatnia konferencja ministerialna członków WTO w Buenos Aires w grudniu 2017 r. Nie zdołano w jej trakcie dojść do żadnych wspólnych wniosków i decyzji dotyczących rolnictwa.

Ograniczone efekty wielostronnych negocjacji już w połowie ubiegłej dekady doprowadziły do wyraźnego zwrotu polityk handlowych państw członkowskich WTO w stronę dwustronnych i regionalnych porozumień handlowych. Również UE zaangażowała się w budowanie sieci globalnych powiązań handlowych $\mathrm{z}$ wieloma krajami, w tym $\mathrm{z}$ krajami rozwijającymi się ${ }^{30}$. W rezultacie liczba zawieranych porozumień handlowych UE z państwami trzecimi, $\mathrm{w}$ tym porozumień o strefach wolnego handlu, rośnie. Obecnie UE ma niemal 40 umów handlowych, łącznie z 60 państwami ${ }^{31}$. Porozumienia te pozwoliły na ekspansję $\mathrm{w}$ handlu zagranicznym, $\mathrm{w}$ tym na zwiększenie wymiany handlowej produktami rolno-spożywczymi. Niektóre rynki były jednak trudno dostępne. Od 2007 r. UE prowadzi trudne negocjacje z państwami ASEAN (Stowarzyszenie Azji Południowo-Wschodniej). Początkowo negocjacje te prowadzone były z całym blokiem, obecnie z każdym z państw członkowskich ASEAN oddzielnie. Próby wynegocjowania porozumienia handlowego $\mathrm{z}$ innymi blokami handlowymi Wspólnotą Andyjską i MERCOSUR - również nie przyniosły dotąd rezultatu. Negocjacje z Indiami w sprawie utworzenia strefy wolnego handlu, rozpoczęte w 2007 r., zostały zawieszone w połowie 2013 r. Pod koniec 2016 r., po objęciu urzędu prezydenta USA przez Donalda Trumpa, zawieszone zostały również rozmowy w sprawie Transatlantyckiego porozumienia w dziedzinie handlu i inwestycji (TTIP), zakładającego utworzenie strefy wolnego handlu między UE i USA. Choć rozbudowana sieć umów i relacji handlowych UE ze światem zapewniała w ostatnich latach bardzo dobre warunki rozwoju unijnego ekspor-

${ }^{28}$ K. Kosior, Wplyw uwarunkowań makroekonomicznych, op. cit., s. 19.

29 W Nairobi zdecydowano o całkowitym zniesieniu subsydiów eksportowych, jednak te od 2007 r. - w związku z wysokimi cenami produktów rolnych na rynkach światowych - rzadko były stosowane. W kluczowych kwestiach związanych ze stosowaniem barier pozataryfowych i innych instrumentów krajowych, ograniczających międzynarodowy handel produktami rolno-spożywczymi, negocjacje nie posunęły się do przodu.

${ }^{30}$ S. Gstöhl, D. De Bièvre, The Trade Policy of the European Union, Palgrave, London 2018, s. 176.

${ }_{31}$ Zob. Overview of FTA and other trade negotiations, European Commission, updated May 2018, http://trade.ec.europa.eu/doclib/docs/2006/december/tradoc_118238.pdf. 
tu, w tym eksportu polskiej żywności, obserwowane obecnie nasilanie się tendencji protekcjonistycznych, w tym eskalowanie konfliktów handlowych, może negatywnie wpływać na perspektywy dalszego zwiększania wartości i wielkości obrotów handlowych z zagranicą.

\section{Członkostwo w Unii Europejskiej - dostęp do wspólnego rynku UE i udział w politykach unijnych}

Członkostwo w UE pozostaje kluczowym czynnikiem wpływającym na konkurencyjność polskiego sektora rolno-spożywczego. Wraz z przystąpieniem do wspólnoty w 2004 r. polscy producenci żywności uzyskali dostęp do liczącego $500 \mathrm{mln}$ konsumentów unijnego rynku wewnętrznego. Od tego czasu następuje systematyczny wzrost i poprawa wyników handlowych Polski produktami rolno-spożywczymi. Wymiana handlowa z państwami członkowskimi UE stanowi aż 80\% wartości handlu rolno-spożywczego Polski ${ }^{32}$. Równocześnie Polska, jako członek UE, systematycznie wzmacnia swoją pozycję na rynkach światowych. Wysokie wymogi w zakresie zapewniania bezpieczeństwa i jakości żywności, nakładane na wszystkich producentów w UE, pozytywnie wpływają na wizerunek i reputację polskiej żywności jako żywności o wysokiej jakości i bezpiecznej dla konsumentów. Przedsiębiorstwa przemysłu spożywczego podkreślają, że harmonizacja prawa żywnościowego w UE, odnosząca się zarówno do ogólnych zasad regulujących kwestie produkcji, przetwórstwa i dystrybucji żywności, jak i szczegółowych procedur dotyczących zarządzania bezpieczeństwem i jakością żywności, jest obecnie jednym z głównych elementów wzmacniających ich konkurencyjność na rynku europejskim i globalnym ${ }^{33}$.

Na poprawę konkurencyjności polskiego sektora rolno-spożywczego duży wpływ miały i wciąż mają fundusze unijne. Jeszcze przed przystąpieniem do UE przedsiębiorstwa sektora rolno-spożywczego korzystały ze wsparcia finansowego w ramach funduszy przedakcesyjnych. Dzięki tym środkom możliwe było przyspieszenie procesów modernizacji i dostosowanie zakładów przetwórczych do standardów obowiązujących w UE, co było warunkiem dopuszczenia do handlu na wspólnym rynku. Wraz z uzyskaniem członkostwa w UE polska gospodarka żywnościowa objęta została wsparciem ze środków polityki strukturalnej i WPR. Dostęp do funduszy strukturalnych UE istotnie przyspieszył proces unowocześniania przedsiębiorstw przemysłu spożywczego w Polsce. Finansowany z projektów unijnych i środków własnych zakup nowoczesnych maszyn i urządzeń przyczynił się do znacznego podniesienia poziomu tech-

32 I. Szczepaniak, Przewagi komparatywne w polskim handlu produktami rolno-spożywczymi [w:] Konkurencyjność polskich producentów żywności i jej determinanty (3), red. I. Szczepaniak, seria „Monografie Programu Wieloletniego 2015-2019”, nr 67, IERiGŻ-PIB, Warszawa 2017, s. 55.

33 The competitive position of the European food and drink industry, Final Report, ECSIP Consortium, Publications Office of the European Union, Luxembourg 2016. 
nologicznego przetwórstwa żywności. W rezultacie obecnie, pod względem technologii przetwórstwa, przedsiębiorstwa przemysłu spożywczego w Polsce nie różnią się od najbardziej nowoczesnych zakładów w krajach UE ${ }^{34}$. Unijne dotacje strukturalne nadal stanowią ważne źródło finansowania inwestycji ukierunkowanych na poprawę wydajności procesów produkcyjnych i jakości wytwarzanych produktów żywnościowych. W latach 2014-2020 ogólna pula wsparcia dla polskiej gospodarki w ramach funduszy strukturalnych i Funduszu Spójności ma przekroczyć 82 mld euro. Znaczna część tych środków przeznaczana jest na projekty, których celem jest wzmacnianie potencjału konkurencyjnego polskich przedsiębiorstw, $w$ tym także przedsiębiorstw funkcjonujących w ramach łańcucha żywnościowego.

Podstawowy w łańcuchu żywnościowym sektor rolnictwa wspierany jest bezpośrednio $\mathrm{z}$ budżetu WPR. Z I filara WPR wspierane są dochody rolnicze (za pomocą płatności bezpośrednich) i w ograniczonym stopniu rynki rolne, w ramach II filara finansowane są działania rozwojowe i strukturalne na obszarach wiejskich. Pod względem wysokości wsparcia w UE, i także w Polsce, kluczowy pozostaje I filar WPR. Choć w pierwszych latach członkostwa w UE polscy rolnicy otrzymywali tylko część płatności bezpośrednich, to w wyniku konwergencji zewnętrznej następuje stopniowe wyrównywanie różnic w poziomach płatności między państwami członkowskimi. Obecnie Polska jest głównym beneficjentem netto budżetu WPR w UE. Transfery do polskiego rolnictwa z budżetu WPR sięgały w ostatnich latach ok. 5 mld euro rocznie (tabela 1).

Za sprawą dotacji inwestycyjnych i transferów bezpośrednich nastąpiło przyspieszenie procesów koncentracji produkcji, zarówno w rolnictwie, jak i w przemyśle spożywczym ${ }^{35}$. Objęcie polskiego rolnictwa mechanizmami WPR pozytywnie wpływało również na stabilność krajowej bazy surowcowej dla przemysłu spożywczego. Sama polityka rolna UE w ostatnich latach istotnie się zmieniła - nastąpił wyraźny zwrot w stronę wzmacniania orientacji rynkowej i lepszego ukierunkowania wsparcia, tak by poprawić długoterminową produktywność, zrównoważony rozwój i wydajność w sektorze rolnym. Obecnie WPR kładzie nacisk na płatności, które nie są powiązane z produkcją rolną, co pozwala producentom bardziej elastycznie reagować na sygnały rynkowe. Równocześnie, w odpowiedzi na potrzebę zapewnienia trwałych podstaw rozwoju sektora rolno-spożywczego w UE, zwiększane jest znaczenie płatności powiązanych $\mathrm{z}$ ochroną środowiska i klimatu.

${ }^{34}$ A. Kowalski, Niespodziewany sukces przemysłu spożywczego, „Gazeta Bankowa” z 16 grudnia 2017 r., http://wgospodarce.pl/informacje/44004-niespodziewany-sukces-przemyslu-spozywczego.

${ }_{35}$ M. Wigier, Pomoc publiczna dla polskiego sektora żywnościowego [w:] Przemyst spo$\dot{z} y w c z y$ - makrootoczenie, inwestycje, ekspansja zagraniczna, red. I. Szczepaniak, K. Firlej, Uniwersytet Ekonomiczny w Krakowie, IERiGŻ-PIB, Kraków-Warszawa 2015, s. 76. 


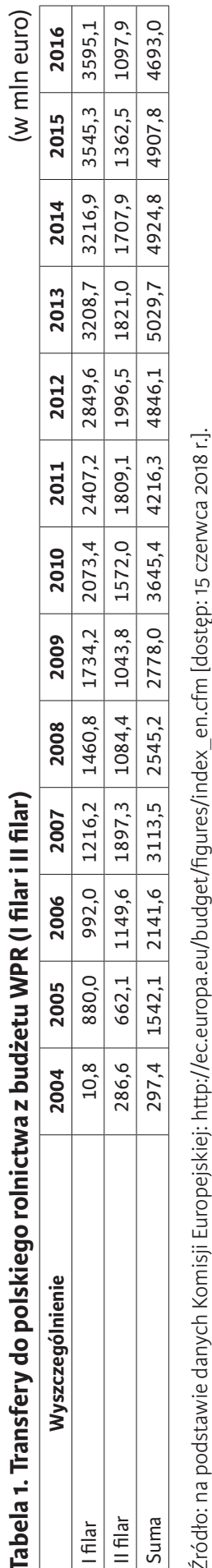

\begin{tabular}{|c|c|c|c|c|c|c|c|c|c|}
\hline & $\begin{array}{l}0 \\
\sim^{\circ}\end{array}$ & ㅇ & $\begin{array}{l}l^{\circ} \\
0^{\circ}\end{array}$ & $\begin{array}{l}0 \\
-i\end{array}$ & $\hat{i}$ & $\begin{array}{l}0 \\
0 \\
0 \\
n\end{array}$ & $\begin{array}{l}\stackrel{P}{2} \\
\stackrel{2}{N} \\
\sim\end{array}$ & . & \\
\hline & $\stackrel{\circ}{m}$ & $\stackrel{\infty}{\circ}$ & $\mid \begin{array}{l}\mathfrak{w} \\
\infty\end{array}$ & ô & $\stackrel{m}{i}$ & 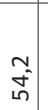 & 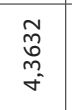 & $\stackrel{\sim}{\tilde{N}}$ & $\hat{\sim}$ \\
\hline & $\begin{array}{c}\infty \\
m^{-}\end{array}$ & $\stackrel{\infty}{\circ}$ & $\hat{a}^{\circ}$ & $\hat{i}$ & $\begin{array}{l}0 \\
\stackrel{T}{T}\end{array}$ & $\begin{array}{l}\overrightarrow{1} \\
\vec{n}\end{array}$ & 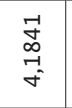 & $\begin{array}{l}\vec{\sigma} \\
\vec{r}\end{array}$ & $\begin{array}{l}0 \\
\text { í }\end{array}$ \\
\hline & $\stackrel{m}{m}$ & $\widehat{\sigma}$ & $\begin{array}{l}n \\
-1 \\
7\end{array}$ & $\overrightarrow{0}$ & $\begin{array}{l}0 \\
\tilde{r}\end{array}$ & $\begin{array}{c}m \\
0 \\
n \\
n\end{array}$ & $\begin{array}{l}\underset{+}{\infty} \\
\underset{\infty}{\rightarrow} \\
\stackrel{+}{+}\end{array}$ & $\underset{-1}{\stackrel{O}{7}}$ & $\hat{\circ}$ \\
\hline ర్ & $\stackrel{t}{-}$ & $\widehat{6}$ & $\begin{array}{l}\vec{\sigma} \\
\vec{m}\end{array}$ & $\begin{array}{l}\infty \\
0^{-}\end{array}$ & $\stackrel{\vec{H}}{+}$ & 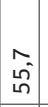 & 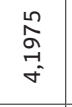 & $\begin{array}{l}n \\
\stackrel{n}{0} \\
-1\end{array}$ & $\tilde{o}_{0}^{m}$ \\
\hline ర్ & $\begin{array}{l}0 \\
-i\end{array}$ & $\hat{\imath}$ & $\begin{array}{c}\vec{\sigma} \\
\vec{m} \\
\vec{r}\end{array}$ & $\hat{m}$ & $\hat{r}$ & $\begin{array}{c}\hat{m} \\
\tilde{n}\end{array}$ & $\begin{array}{l}\text { f } \\
\text { D } \\
\stackrel{+}{*} \\
\forall\end{array}$ & $\begin{array}{l}\stackrel{n}{\stackrel{2}{r}} \\
-\end{array}$ & $\stackrel{m}{\sim}$ \\
\hline กั & o & ถి & 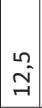 & $\stackrel{a}{m}$ & $\begin{array}{l}\infty \\
\stackrel{+}{+}\end{array}$ & $\begin{array}{l}\text { - } \\
\dot{1} \\
\text { in }\end{array}$ & $\begin{array}{l}\stackrel{0}{\sim} \\
\underset{\sim}{*} \\
\sim\end{array}$ & $\begin{array}{l}\hat{a} \\
\dot{f}\end{array}$ & $\stackrel{0}{-}$ \\
\hline סั & $\begin{array}{l}0 \\
\dot{m}\end{array}$ & $\widetilde{\sigma}$ & $\begin{array}{l}\vec{y} \\
\vec{z}\end{array}$ & $\stackrel{0}{i}$ & $\stackrel{m}{i}$ & $\begin{array}{c}-1 \\
\text { n. } \\
n\end{array}$ & $\begin{array}{l}\text { fे } \\
\text { oे } \\
\text { mे }\end{array}$ & $\begin{array}{l}\frac{2}{6} \\
6\end{array}$ & $\vec{\sim}$ \\
\hline ठे & $\stackrel{\infty}{\sim}$ & ৪ & $\begin{array}{l}\overrightarrow{1} \\
\mathfrak{z}\end{array}$ & $\nabla$ & $\stackrel{m}{\stackrel{n}{i}}$ & $\begin{array}{c}\vec{a} \\
\sigma \\
\sigma\end{array}$ & $\begin{array}{l}\stackrel{2}{\sim} \\
\text { m } \\
\text { r }\end{array}$ & $\underset{m}{\stackrel{N}{N}}$ & $\begin{array}{l}\infty \\
0 \\
0\end{array}$ \\
\hline ర్ & $\stackrel{\mathcal{F}}{f}$ & 员 & $\begin{array}{l}\text { Ln } \\
\sigma\end{array}$ & $\stackrel{\mathcal{F}}{\sim}$ & $\stackrel{0}{\tilde{r}}$ & $\begin{array}{l}m \\
0 \\
o \\
o\end{array}$ & $\begin{array}{l}\stackrel{\vec{I}}{\underset{n}{n}} \\
\stackrel{m}{m}\end{array}$ & $\begin{array}{l}\infty \\
\infty \\
0\end{array}$ & $\vec{\infty}_{\infty}^{-1}$ \\
\hline 8 & $\stackrel{\circ}{\wedge}$ & nn & $\begin{array}{l}n \\
-1 \\
-1\end{array}$ & $\stackrel{0}{i}$ & $\begin{array}{l}a \\
\vec{i}\end{array}$ & $\begin{array}{l} \\
\tilde{f} \\
\dot{f}\end{array}$ & 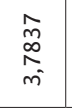 & $\stackrel{\infty}{\stackrel{\infty}{N}}$ & $\vec{m}$ \\
\hline ఫ్ & శ్ & 도 & $\begin{array}{l}\infty \\
\underset{-}{-}\end{array}$ & $\underset{r}{m}$ & $\begin{array}{l}0 \\
\tilde{r}^{-}\end{array}$ & $\begin{array}{l}a \\
b \\
b \\
\sigma\end{array}$ & $\begin{array}{l}\text { مे } \\
\text { مे } \\
0 \\
\text { m. }\end{array}$ & $\begin{array}{l}m \\
\infty \\
i\end{array}$ & $\hat{i}$ \\
\hline 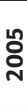 & $\begin{array}{l}n \\
m \\
m\end{array}$ & 음 & \begin{tabular}{l}
0 \\
\multirow{-}{*}{}
\end{tabular} & $\stackrel{N}{N}$ & I $^{\prime}$ & $\begin{array}{l}\tau \\
\vdots \\
\sigma \\
\sigma\end{array}$ & 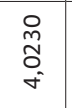 & $\stackrel{\infty}{\stackrel{\infty}{\sim}} \underset{\sim}{\sim}$ & $\hat{0}$ \\
\hline ఫ & in & $g$ & $\left|\begin{array}{l}0 \\
\hat{\sigma}\end{array}\right|$ & $\stackrel{0}{m}$ & ؟ & $\mid \begin{array}{c}0 \\
\text { ì }\end{array}$ & 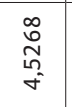 & \begin{tabular}{l}
\multirow{\alpha}{*}{} \\
mे
\end{tabular} & $\stackrel{n}{7}$ \\
\hline$\sum$ & 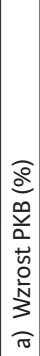 & 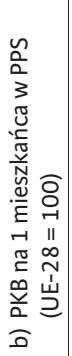 & 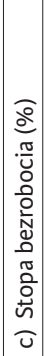 & 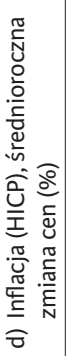 & 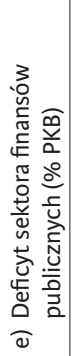 & 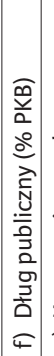 & 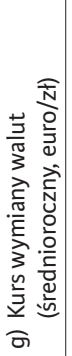 & 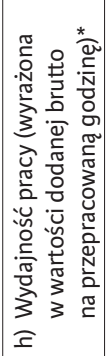 & 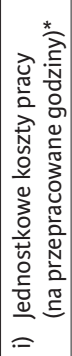 \\
\hline
\end{tabular}

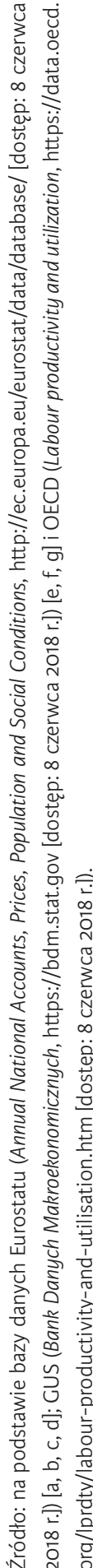


Podsumowując, należy stwierdzić, że integracja z UE zapewnia polskiej gospodarce żywnościowej bardzo dobre warunki rozwoju. Świadczy o tym nie tylko rosnąca produkcja globalna polskiego przemysłu spożywczego, ale również utrzymujące się od $2004 \mathrm{r}$. dodatnie saldo w handlu produktami rolno-spożywczymi. Obecnie Polska zajmuje ósme miejsce wśród najważniejszych eksporterów żywności w UE. Wobec wielu korzyści wynikających z procesów integracji gospodarczej, niepokojącymi zjawiskami są obecne tendencje do dezintegracji w UE. Dotkliwą manifestacją tych tendencji jest niedawna decyzja Wielkiej Brytanii o wystąpieniu z UE. Polski sektor żywnościowy może zostać szczególnie dotknięty skutkami brexitu ${ }^{36}$. Jedną z bardziej istotnych konsekwencji wystąpienia Wielkiej Brytanii będzie luka w dochodach UE skutkująca możliwym ograniczeniem budżetu WPR i funduszy strukturalnych. Możliwe jest również załamanie w polskim eksporcie do Wielkiej Brytanii najważniejszych grup produktów rolno-spożywczych.

\section{Uwarunkowania krajowe - sytuacja makroekonomiczna Polski}

Uwarunkowania wewnętrzne, związane ze stanem polskiej gospodarki i kierunkami jej rozwoju, zapewniały w ostatnich latach dobre podstawy do poprawy i wzmacniania konkurencyjności przedsiębiorstw sektora rolno-spożywczego. Od momentu uzyskania członkostwa w UE polska gospodarka rozwija się dynamicznie i pozostaje jedną z najbardziej zrównoważonych pod względem makroekonomicznym gospodarek unijnych. Obecnie Polska należy do grupy państw o najwyższej dynamice wzrostu gospodarczego w UE. Średnie tempo wzrostu PKB między rokiem 2004 a 2017 wynosiło w ujęciu realnym 3,9\%. Równocześnie następowało stopniowe zmniejszanie dystansu, jaki dzieli polską gospodarkę od pozostałych gospodarek europejskich. Wartość PKB na jednego mieszkańca w Polsce, $w$ relacji do średniej w UE-28 i według parytetu siły nabywczej, wzrosła z 49\% w 2004 r. do $70 \%$ w 2017 r. (tabela 2).

W ostatnich latach głównym motorem napędzającym wzrost gospodarczy w Polsce był rosnący popyt krajowy, w tym szczególnie konsumpcja prywatna. Sprzyjała temu bardzo dobra sytuacja na rynku pracy, wzrost płac oraz zwiększone transfery fiskalne do gospodarstw domowych ${ }^{37}$. W latach 2004-2017 bezrobocie w Polsce spadło z 19\% do 6,6\% ludności aktywnej zawodowo. Równocześnie wskaźnik cen towarów i usług konsumpcyjnych kształtował się na poziomie, który nie zagrażał aktywności gospodarczej przedsiębiorstw i konsumpcji gospodarstw domowych. Średni poziom inflacji w Polsce w omawianym

${ }^{36}$ Zob. więcej K. Kosior, Ł. Ambroziak, Brexit - potential implications for the Polish food sector [w:] The Common Agricultural Policy of the European Union - the present and the future. EU Member States point of view, red. M. Wigier, A. Kowalski, seria „Monographs of Multi-annual Programme 2015-2019”, No. 73.1, IAFE-NRI, Warsaw 2018.

372018 European Semester. Country Report Poland, European Commission, Brussels, 7.3.2018 SWD(2018) 219 final, s. 4. 
okresie wynosił 2,12\%. Stabilności makroekonomicznej kraju sprzyjała również stosunkowo korzystna relacja deficytu sektora finansów publicznych do PKB. Wyraźnie zwiększony deficyt $\mathrm{w}$ finansach publicznych w Polsce odnotowano w 2009 i 2010 r., tj. w okresie spowolnienia gospodarczego na świecie i w UE, który był spowodowany globalnym kryzysem finansowym i kryzysem w strefie euro. Od czterech lat deficyt sektora finansów publicznych w relacji do PKB systematycznie spada - w 2014 r. wyniósł 3,6\%, w 2015 r. - 2,6\%, w 2016 r. - 2,5\%, a w 2017 r. - 1,7\%. Polska jest też jednym z niewielu państw członkowskich UE, które spełniają wymogi unijne w zakresie relacji długu publicznego do PKB. W okresie 2004-2017 dług publiczny w relacji do PKB wahał się od 44\% do $56 \%$, tj. poniżej dopuszczalnego w UE progu zadłużenia (60\%).

Dużą rolę w umacnianiu konkurencyjności polskich producentów żywności odgrywały czynniki kosztowo-cenowe. Pozytywny wpływ na konkurencyjność polskiego eksportu rolno-spożywczego miał m.in. kurs wymiany walut (zł/euro). W 2009 r., po kilku latach umacniania się polskiej waluty, nastąpiła wyraźna deprecjacja złotego wobec euro. Utrzymywanie się w ostatnich latach stosunkowo stabilnego kursu wymiany złotego do euro, wraz z dalszą deprecjacją polskiej waluty w 2016 i 2017 r., wzmacniało konkurencyjność kosztową polskiego eksportu rolno-spożywczego. Deprecjacja złotego prowadziła do wzrostu wolumenu polskiego eksportu żywności i zwierząt żywych do UE [w latach 2004-2016 wzrost o 1 punkt procentowy (pkt proc.) realnego kursu złotego do euro, deflowanego jednostkowymi kosztami pracy, przyczyniał się do wzrostu wolumenu tego eksportu o $0,31 \%]^{38}$.

Stosunkowo niskie koszty pracy w Polsce (średnio o $2 / 3$ mniejsze niż przeciętnie w UE-15) oraz umiarkowane tempo ich wzrostu pozwalały polskim producentom żywności na utrzymywanie cenowych przewag nad pozostałymi konkurentami na rynkach zagranicznych. W 2004 r. godzinowy koszt pracy w Polsce wynosił 4,9 euro, w 2008 r. - 7,6 euro, w 2012 r. - 7,9 euro, a w 2016 r. 8,6 euro. W tym samym czasie średni godzinowy koszt pracy w całej UE (dla 28 państw członkowskich) wynosił odpowiednio: 19,8 euro, 21,9 euro, 24,5 euro i 26,2 euro ${ }^{39}$. W 2017 r. godzinowy koszt pracy wzrósł w Polsce do 9,4 euro, nadal jednak był to jeden z najniższych wyników w UE (niższe godzinowe koszty pracy miały jedynie: Bułgaria, Rumunia, Litwa i Łotwa). Równocześnie, według danych OECD, wydajność pracy w Polsce, mierzona PKB na jedną przepracowaną godzinę, wzrosła z 21,39 dolarów US w 2004 r. do 30,35 dolarów US

38 Ł. Ambroziak, I. Szczepaniak, Ryzyko kursowe a handel zagraniczny produktami rolno-spożywczymi Polski [w:] Ryzyko w gospodarce żywnościowej - teoria i praktyka, red. J. Góral, M. Wigier, seria „Monografie Programu Wieloletniego 2015-2019”, nr 48, IERiGŻ-PIB, Warszawa 2017, s. 102-103.

39 Baza danych Eurostatu, Hourly labour costs, April 2018, http://ec.europa.eu/eurostat/ statistics-explained/index.php/Hourly_labour_costs\#Hourly_labour_costs_ranged_between_EUR.C2.A04.9_and_42.5_in_2017 [dostęp: 28 czerwca 2018 r.]. 
w 2017 r. $^{40}$. W latach 2004-2016 wydajność pracy w Polsce rosła na ogół szybciej niż jednostkowe koszty pracy, co sprzyjało utrzymywaniu przewag cenowo-kosztowych w handlu zagranicznym.

Choć prognozy dla polskiej gospodarki na najbliższe lata są korzystne (w 2018 r. prognozowany jest wzrost gospodarczy na poziomie 4,2\%, w $2019 \mathrm{r}$. na poziomie $3,6 \%{ }^{41}$ ), dynamika zmian na rynku pracy skłania do twierdzenia o możliwości pogorszenia się w niedługim horyzoncie czasowym konkurencyjności kosztowej polskiego eksportu ${ }^{42}$. W związku z oczekiwanym dalszym wzrostem popytu na pracę bardzo prawdopodobny jest silniejszy wzrost jednostkowych kosztów pracy. Prawdopodobne będzie więc pogłębianie się różnicy między kosztami i wydajnością pracy, co może negatywnie wpływać na konkurencyjność polskiego eksportu, w tym eksportu żywności.

\section{Rozwój handlu zagranicznego produktami rolno-spożywczymi Polski}

\section{Ogólne wyniki handlu rolno-spożywczego}

W okresie członkostwa Polski w Unii Europejskiej nastąpił dynamiczny wzrost obrotów handlu zagranicznego produktami rolno-spożywczymi (wykres 1). Tendencja wzrostowa ujawniła się już w roku akcesji (2004), kiedy to obroty handlowe Polski produktami rolno-spożywczymi zwiększyły się o blisko $30 \%$ w porównaniu z rokiem 2003. Wartość wymiany, dzięki utrzymującemu się wzrostowi zarówno eksportu, jak i importu, zwiększała się także w kolejnych latach. Wyjątek stanowil jedynie rok 2009, kiedy na skutek spowolnienia gospodarczego wywołanego przez światowy kryzys finansowy, obroty zmniejszyły się o prawie $11 \%$ w porównaniu z rokiem poprzednim ${ }^{43}$. W 2017 r. lączna wartość obrotów handlowych Polski produktami rolno-spożywczymi wyniosła prawie 49,6 mld dolarów US, w tym eksport osiągnął poziom 29,6 mld dolarów US, a import 20,0 mld dolarów US. W porównaniu z rokiem 2004 oznacza to ponadczterokrotny wzrost obrotów handlowych, w tym samego eksportu - czteroipółkrotny, a importu - przeszło trzyipółkrotny. Od momentu akcesji Polski do UE dodatnie saldo wymiany handlowej produktami rolno-spożywczymi także przeważnie zwiększało się (z wyjątkiem lat 2008 i 2011). W 2017 r. wartość salda

40 Baza danych OECD, https://data.oecd.org/lprdty/gdp-per-hour-worked.htm [dostęp: 28 czerwca 2018 r.].

${ }^{41} 2018$ European Semester, op. cit.

${ }^{42}$ K. Kosior, Wpływ uwarunkowań makroekonomicznych, op. cit., s. 29.

43 W latach 2015-2016 nastąpił spadek obrotów handlowych zarówno Polski ogółem, jak i sektora rolno-spożywczego wyrażonych w dolarach US, co wynikało ze znacznego osłabienia złotego i euro w stosunku do dolara US. Dane dotyczące polskiego handlu zagranicznego wyrażone w euro, pochodzące z Ministerstwa Finansów, nie potwierdziły tego spadku. 
obrotów przekroczyła 9,6 mld dolarów US, co oznacza, że była ponaddziewięciokrotnie wyższa niż w 2004 r. Dla porównania, w tym samym okresie skumulowany wskaźnik wzrostu PKB, wyrażonego w cenach stałych, wyniósł ok. $163 \%{ }^{44}$. Dynamika wzrostu eksportu i salda handlu zagranicznego produktami rolno-spożywczymi znacznie przewyższa więc dynamikę PKB, potwierdzając proeksportowy charakter rozwoju tego sektora gospodarki w Polsce.

Wykres 1. Handel rolno-spożywczy Polski, lata 2004-2017 ～(w mln dolarów US)

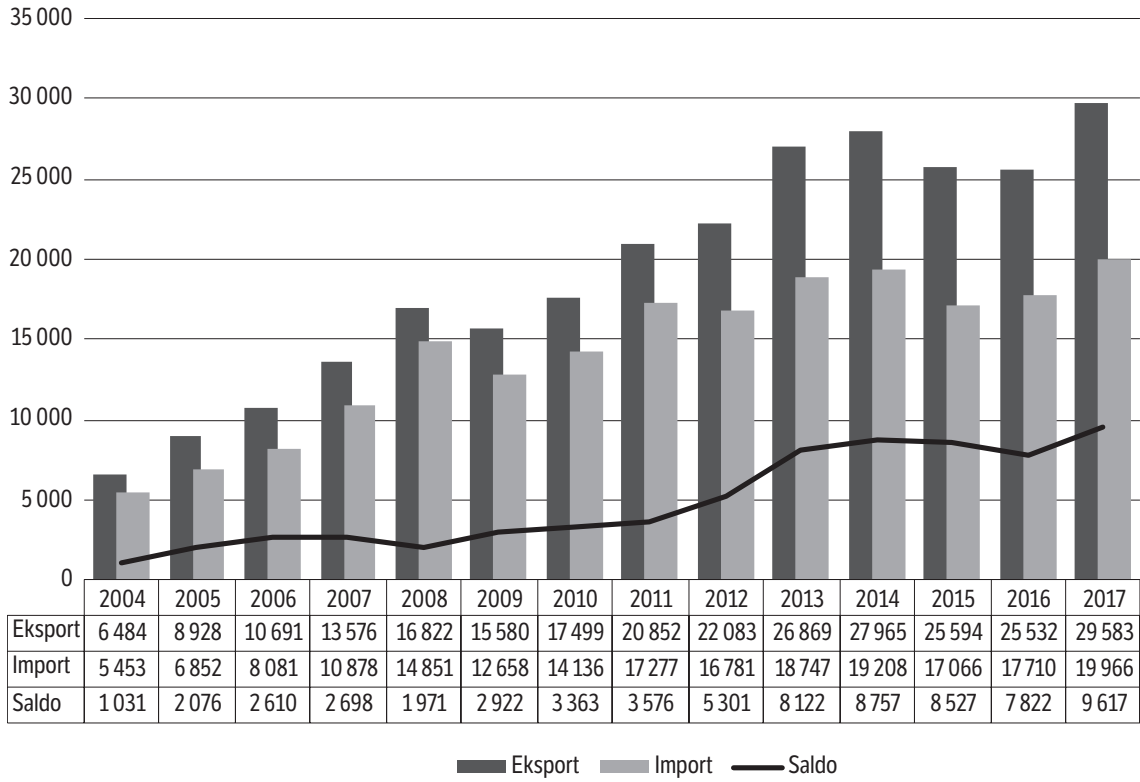

Źródło: na podstawie danych WITS-Comtrade, https://wits.worldbank.org/ [dostęp: 25 czerwca 2018 r.].

Wymiana handlowa produktami rolno-spożywczymi Polski ma charakter asymetryczny, co oznacza, że zarówno w eksporcie, jak i w imporcie dominują państwa członkowskie Unii Europejskiej. W strukturze geograficznej polskiego eksportu rolno-spożywczego udział UE sięga ok. 80\% (w 2017 r. wyniósł 80,8\% i był wyższy o 6,3 pkt proc. w porównaniu z 2004 r.), a w strukturze geograficznej importu - ok. 70\% (w 2017 r. wyniósł 69,1\%, tj. był wyższy o 5 pkt proc. niż w 2004 r.). W analizowanym okresie następowała systematyczna poprawa salda obrotów handlowych produktami rolno-spożywczymi z państwami UE, aż do poziomu przeszło 10,1 mld dolarów US w 2017 r. Świadczy to wyraźnie o tym, że polscy producenci żywności pozostają w dalszym ciągu wysoce konkurencyjni

${ }_{44}$ Baza danych GUS, https://stat.gov.pl/wskazniki-makroekonomiczne/ [dostęp: 25 czerwca 2018 r.]. 
na rynku unijnym. Dodatnie saldo handlu zagranicznego z państwami członkowskimi UE z nadwyżką pokrywa deficyt w wymianie handlowej z krajami spoza UE i w efekcie powoduje, że polski sektor rolno-spożywczy niezmiennie osiąga dodatni bilans handlowy.

\section{Wyniki handlu rolno-spożywczego w układzie towarowym}

W 2017 r. do najważniejszych grup produktów (działów HS) w eksporcie rolno-spożywczym Polski należały: mięso i podroby jadalne, tytoń i wyroby tytoniowe, produkty mleczarskie, przetwory zbożowe i pieczywo cukiernicze, różne przetwory spożywcze, przetwory z mięsa i ryb, kakao i przetwory z kakao, ryby i owoce morza, przetwory z owoców i warzyw oraz owoce i orzechy. Na tych dziesięć grup produktów przypadało $76,2 \%$ polskiego eksportu rolno-spożywczego (tabela 3). W latach 2004-2017 zwiększyła się wartość eksportu większości grup produktów rolno-spożywczych. W dwunastu działach HS odnotowano wzrost wyższy od przeciętnego, najwyższy w przypadku: zbóż, tytoniu i wyrobów tytoniowych, tłuszczów i olejów, kawy, herbaty i przypraw, mięsa i podrobów jadalnych oraz przetworów zbożowych i pieczywa cukierniczego. W efekcie tych zmian zaszło wyraźne przetasowanie na liście dziesięciu głównych grup towarowych - zniknęły z niej warzywa oraz cukry i wyroby cukiernicze, a pojawily się przetwory z mięsa i ryb oraz tytoń i wyroby tytoniowe. Zwiększył się także stopień koncentracji polskiego eksportu rolno-spożywczego na rynek światowy, gdyż w 2004 r. na dziesięć głównych grup towarowych przypadało $74,6 \%$ eksportu.

Do najważniejszych grup towarowych (działów HS) w imporcie rolno-spożywczym Polski w 2017 r. należały: ryby i owoce morza, owoce i orzechy, odpady i pasze dla zwierząt, mięso i podroby jadalne, kakao i przetwory z kakao, różne przetwory spożywcze, produkty mleczarskie, tłuszcze i oleje, napoje oraz przetwory zbożowe i przetwory cukiernicze. Udział tych dziesięciu grup produktów w polskim imporcie rolno-spożywczym wynosił 67,8\% (tabela 3). W latach 2004-2017 zwiększyła się wartość importu wszystkich grup produktów rolno-spożywczych. W jedenastu działach HS odnotowano wzrost wyższy od przeciętnego, najwyższy w następujących grupach produktów: produkty mleczarskie, pozostałe produkty roślinne, zwierzęta żywe, mięso i podroby oraz przetwory zbożowe i pieczywo cukiernicze. W efekcie zaszły istotne zmiany na liście dziesięciu głównych grup towarowych - zniknęły z niej kawa, herbata i przyprawy oraz zboża, a pojawily się produkty mleczarskie oraz przetwory zbożowe i przetwory cukiernicze. Na zbliżonym poziomie utrzymał się stopień koncentracji polskiego importu rolno-spożywczego, gdyż w 2004 r. na dziesięć głównych grup towarowych przypadało 67,9\% importu.

Saldo obrotów handlowych produktami rolno-spożywczymi Polski ogólem w 2017 r. dodatnie było w przypadku 13 działów HS (w 2004 r. - 10 działów), najwyższa jego wartość dotyczyła handlu mięsem i podrobami, tytoniem 
i wyrobami tytoniowymi, przetworami zbożowymi i pieczywem cukierniczym, produktami mleczarskimi oraz przetworami z mięsa i ryb. Największy deficyt generowała wymiana handlowa owocami i orzechami, odpadami i paszami dla zwierząt, tłuszczami i olejami oraz rybami i owocami morza.

Dynamicznemu rozwojowi handlu rolno-spożywczego w okresie członkostwa Polski w UE towarzyszył zatem wyraźny wzrost koncentracji towarowej eksportu, a co za tym idzie - specjalizacji eksportowej. Zaobserwowane zmiany struktury towarowej eksportu i importu świadczą ponadto o rosnącej dywersyfikacji towarowej obu strumieni handlu, tj. rozszerzaniu oferty eksportowej produktów i imporcie nowych asortymentów towarów.

\section{Ocena pozycji konkurencyjnej Polski w handlu produktami rolno-spożywczymi}

\section{Metoda badania}

Do oceny pozycji konkurencyjnej Polski w handlu rolno-spożywczym wykorzystano dwa mierniki konkurencyjności, tj. wskaźnik pokrycia importu eksportem (TC, trade coverage) oraz wskaźnik ujawnionych przewag komparatywnych B. Balassy (RCA, revealed comparative advantage). Mierniki te należą do grupy wskaźników konkurencyjności ex post, tj. odnoszą się do pomiaru konkurencyjności w przeszłości ${ }^{45}$.

Wskaźnik pokrycia importu eksportem TC obliczono według następującej formuły:

$$
T C_{i k}=\frac{X_{i k}}{M_{i k}} \cdot 100
$$

gdzie:

$T C_{i k}$ - wskaźnik pokrycia importu eksportem w handlu produktem $i$ przez kraj $k$ z określonym krajem (grupą krajów),

$X_{i k}$ - eksport grupy produktów $i$ przez kraj $k$ do określonego kraju (grupy krajów),

$M_{i k}$ - import grupy produktów $i$ przez kraj $k \mathrm{z}$ określonego kraju (grupy krajów).

Wskaźnik TC określa, w jakim stopniu wydatki na dobra importowane są pokrywane z wpływów z ich eksportu. Wartość wskaźnika TC większa od 100\% oznacza, że dany kraj ma względną wewnętrzną przewagę nad partnerami, gdyż wartość eksportu przewyższa wartość importu.

\footnotetext{
45 J. Misala, Międzynarodowa konkurencyjność, op. cit., s. 135.
} 


\begin{tabular}{|c|c|c|c|c|c|c|c|c|c|c|c|c|c|c|c|c|c|c|c|c|c|}
\hline \multirow{4}{*}{$\frac{0}{\frac{0}{n}}$} & 유 & \multirow{4}{*}{$\begin{array}{l}\text { n } \\
3 \\
\frac{3}{0} \\
\frac{0}{0} \\
\frac{0}{0} \\
\frac{0}{0} \\
\frac{c}{E} \\
3\end{array}$} & 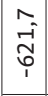 & $\begin{array}{l}\infty \\
\tilde{m}^{-} \\
m \\
m \\
\end{array}$ & $\begin{array}{l}n \\
2 \\
\alpha \\
+ \\
+ \\
1\end{array}$ & $\begin{array}{l}\hat{0} \\
0 \\
0 \\
\infty \\
-1 \\
-1\end{array}$ & $\hat{m}^{2}$ & $\begin{array}{l}\hat{\sigma} \\
\text { ดे } \\
\text { 1 }\end{array}$ & 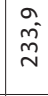 & $\mid \begin{array}{c}0 \\
\hat{1} \\
\hat{0} \\
1\end{array}$ & $\begin{array}{l}\overrightarrow{1} \\
\stackrel{-}{7} \\
1\end{array}$ & 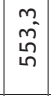 & $\begin{array}{l}0 \\
\text { ले }\end{array}$ & $\begin{array}{l}n \\
\stackrel{n}{\sim} \\
\stackrel{T}{T}\end{array}$ & $\begin{array}{c}0 \\
\infty \\
\infty^{\infty} \\
1\end{array}$ & $\begin{array}{l}\vec{j} \\
\vec{i} \\
i\end{array}$ & \begin{tabular}{|c|c}
$\infty$ \\
$\infty$ \\
0 \\
0 \\
$น$ \\
1
\end{tabular} & \begin{tabular}{|c|}
$\infty$ \\
0 \\
$D$ \\
$\sim$ \\
-1 \\
\end{tabular} & $\begin{array}{l}\sigma \\
\vec{i} \\
\vec{\gamma}\end{array}$ & $\begin{array}{l}n \\
b \\
b^{-} \\
m\end{array}$ & $\begin{array}{l}m \\
\stackrel{1}{1} \\
\vec{b} \\
\rightarrow\end{array}$ \\
\hline & ְֵ & & 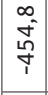 & $\begin{array}{l}0 \\
\infty \\
0 \\
0 \\
N \\
N\end{array}$ & $\begin{array}{l}\vec{f} \\
\vec{f} \\
0 \\
1\end{array}$ & \begin{tabular}{l}
$m$ \\
\multirow{J}{*}{} \\
$\sigma$
\end{tabular} & $\begin{array}{l}m \\
0^{-}\end{array}$ & O & 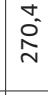 & $\begin{array}{l}\infty \\
\hat{1} \\
\hat{T} \\
\hat{T}\end{array}$ & $m_{1}^{m}$ & \begin{tabular}{|l|l|}
$\infty$ \\
$\vdots$ \\
$\vdots$ \\
$\infty$ \\
$\infty$
\end{tabular} & $\begin{array}{l}0 \\
\stackrel{N}{N}\end{array}$ & 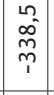 & $\begin{array}{c}\hat{0} \\
0 \\
0 \\
1\end{array}$ & $\begin{array}{l}\infty \\
0^{-}\end{array}$ & $\begin{array}{l}\overrightarrow{-} \\
\stackrel{n}{n} \\
\stackrel{T}{1}\end{array}$ & $\begin{array}{c}n \\
\tilde{N} \\
0 \\
-1 \\
-1 \\
\end{array}$ & $\begin{array}{l}\stackrel{+}{\sim} \\
\stackrel{\mathfrak{n}}{N}\end{array}$ & $\begin{array}{l}\infty \\
\sigma^{0} \\
\sigma\end{array}$ & \begin{tabular}{l}
$m$ \\
$b^{2}$ \\
\multirow{-}{-}{} \\
-1
\end{tabular} \\
\hline & ก) & & $\begin{array}{l}0 \\
a \\
i\end{array}$ & $\begin{array}{c}\stackrel{n}{n} \\
\stackrel{n}{n}\end{array}$ & $\begin{array}{l}a \\
\hat{0} \\
\tilde{r} \\
1\end{array}$ & $\begin{array}{l}0 \\
0 \\
0 \\
0 \\
-1 \\
-1\end{array}$ & $\begin{array}{l}0 \\
-1 \\
-1 \\
-1\end{array}$ & 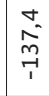 & $\begin{array}{l}n \\
\text { ñ } \\
\text { mo }\end{array}$ & 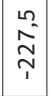 & 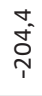 & $\begin{array}{l}2 \\
\stackrel{n}{8} \\
\tilde{m}\end{array}$ & 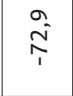 & $\begin{array}{c}0 \\
0 \\
\vec{q} \\
7 \\
T\end{array}$ & $\begin{array}{l}\hat{a} \\
\hat{1}\end{array}$ & $\begin{array}{l}\stackrel{N}{*} \\
\overrightarrow{1}\end{array}$ & 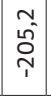 & $\begin{array}{l}0 \\
o \\
i n \\
\text { in }\end{array}$ & $\begin{array}{l}\text { aे } \\
\text { مे }\end{array}$ & 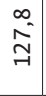 & 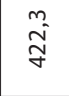 \\
\hline & ర్ & & $\begin{array}{l}\hat{\delta} \\
\stackrel{0}{a}\end{array}$ & $\begin{array}{l}n \\
\alpha \\
\hat{f}\end{array}$ & $\begin{array}{l}0 \\
0 \\
0 \\
0 \\
1\end{array}$ & $\hat{\tilde{A}}$ & 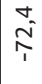 & $\begin{array}{l}0 \\
0 \\
0 \\
1\end{array}$ & $\begin{array}{l}\mathcal{N} \\
\stackrel{f}{m} \\
m\end{array}$ & $\begin{array}{l}\mid \infty \\
\Lambda \\
\Lambda \\
\uparrow \\
1\end{array}$ & 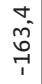 & $\begin{array}{l}n \\
\infty \\
\infty \\
T \\
7 \\
1\end{array}$ & 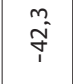 & $\begin{array}{c}\infty \\
\hat{i}^{0}\end{array}$ & $\mid \begin{array}{c}0 \\
-\vec{j} \\
i\end{array}$ & $\stackrel{\circ}{-}$ & $\mid \begin{array}{l}\infty \\
\infty \\
\omega^{\infty} \\
\uparrow \\
\uparrow\end{array}$ & $\begin{array}{l}\hat{N} \\
\hat{N}\end{array}$ & $\begin{array}{c}\stackrel{N}{\infty} \\
\stackrel{\infty}{\sim} \\
\stackrel{N}{n}\end{array}$ & $\begin{array}{l}0 \\
\hat{i}\end{array}$ & $\vec{i}$ \\
\hline \multirow{6}{*}{ 흘 } & & 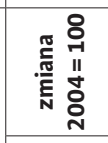 & $\mid \begin{array}{l}\hat{\sigma} \\
\hat{\alpha} \\
\infty\end{array}$ & 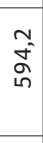 & $\begin{array}{l}a \\
b \\
b \\
b\end{array}$ & $\begin{array}{l}-1 \\
6 \\
0 \\
-1 \\
-1 \\
-1\end{array}$ & 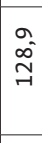 & $\stackrel{n}{m}_{\vec{n}}^{-}$ & $\begin{array}{l}n \\
\delta \\
\stackrel{2}{ }\end{array}$ & $\mid \begin{array}{c}-1 \\
\tilde{S} \\
\mathbf{N}\end{array}$ & $\begin{array}{l}0 \\
-1 \\
m\end{array}$ & $\begin{array}{l}0 \\
0 \\
0 \\
-1 \\
-1\end{array}$ & $\begin{array}{l}m \\
\overrightarrow{-} \\
-\end{array}$ & $\begin{array}{c}m \\
\hat{i} \\
\dot{g}\end{array}$ & $\begin{array}{l}0 \\
\hat{i} \\
\stackrel{0}{N}\end{array}$ & 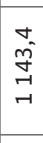 & $\mid \begin{array}{l}m \\
\sigma^{2} \\
m\end{array}$ & $\begin{array}{c}m \\
\tilde{m} \\
m \\
m\end{array}$ & $\begin{array}{l}\hat{\tilde{f}} \\
\hat{m}\end{array}$ & $\begin{array}{l}\infty \\
\tilde{m}^{-} \\
\tilde{q}^{\prime}\end{array}$ & $\begin{array}{l}n \\
\text { مू } \\
\alpha \\
\alpha\end{array}$ \\
\hline & 今े & 的高 & $\begin{array}{c}\infty \\
\stackrel{n}{n} \\
\stackrel{n}{n}\end{array}$ & 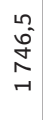 & $\begin{array}{l}0 \\
\infty \\
0 \\
0 \\
N\end{array}$ & $\begin{array}{l}m \\
\tilde{\alpha} \\
\tilde{n} \\
0 \\
-1\end{array}$ & $\stackrel{\sim}{\sim} \underset{\sim}{\sim}$ & $\begin{array}{l}a \\
\delta \\
\delta \\
m\end{array}$ & $\begin{array}{l}n \\
0 \\
0 \\
\end{array}$ & $\begin{array}{c}\infty \\
\mathbb{-} \\
\infty \\
-1 \\
-1\end{array}$ & $\stackrel{m}{\stackrel{m}{n}} \stackrel{n}{N}^{n}$ & $\begin{array}{l}\vec{z} \\
\stackrel{5}{0} \\
\stackrel{m}{n}\end{array}$ & $\begin{array}{l}\infty \\
\stackrel{\sim}{\sim} \\
\stackrel{n}{n}\end{array}$ & $\begin{array}{l}0 \\
0 \\
0 \\
0 \\
0\end{array}$ & $\begin{array}{l}-1 \\
\sigma^{2}\end{array}$ & $\stackrel{\stackrel{N}{m}}{m}$ & $\mid \begin{array}{c}1 \\
\infty \\
0 \\
0 \\
-1 \\
-1\end{array}$ & $\begin{array}{c}\stackrel{m}{\sim} \\
\stackrel{\sim}{\sim}\end{array}$ & $\begin{array}{l}\stackrel{7}{7} \\
\vec{y}\end{array}$ & 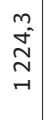 & \begin{tabular}{l}
$\infty$ \\
\multirow{2}{\infty}{} \\
\multirow{\infty}{\infty}{}
\end{tabular} \\
\hline & & \multirow{4}{*}{$\begin{array}{l}\stackrel{2}{2} \\
\frac{3}{5} \\
\frac{\pi}{\sqrt[N]{5}} \\
\frac{5}{3}\end{array}$} & $\hat{m}$ & $\infty$ & $\begin{array}{l}-1 \\
0 \\
0\end{array}$ & N & $\underset{-1}{N}$ & $\stackrel{n}{-1}$ & $\vec{m}$ & 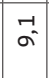 & $\hat{m}$ & $\begin{array}{l}0 \\
i\end{array}$ & $\vec{F}$ & $\begin{array}{c}m \\
m\end{array}$ & $\begin{array}{l}\text { Ln } \\
0\end{array}$ & ָ̃ & in & $\underset{-1}{7}$ & $\vec{i}$ & नु- & $\stackrel{n}{\sim}$ \\
\hline & : & & $\stackrel{\sigma_{m}}{m}$ & $\begin{array}{l}0 \\
\infty^{\circ}\end{array}$ & $\vec{F}$ & $\begin{array}{c}m \\
n^{m}\end{array}$ & $\vec{F}$ & $\stackrel{n}{\sim}$ & $\stackrel{\sigma}{\vec{m}}$ & $\begin{array}{c}m \\
\infty^{2}\end{array}$ & $\begin{array}{l}0 \\
\dot{m}\end{array}$ & $\begin{array}{l}0 \\
\text { i }\end{array}$ & $\underset{r}{m}$ & $\begin{array}{l}\vec{m} \\
\dot{m}\end{array}$ & $\begin{array}{l}0 \\
0^{\circ}\end{array}$ & ž & $\begin{array}{l}\stackrel{\sigma}{ } \\
\dot{\sigma}\end{array}$ & $\underset{r}{m}$ & $\stackrel{m}{\sim}$ & $\begin{array}{l}t \\
b^{\prime}\end{array}$ & $\stackrel{\circ}{\circ}$ \\
\hline & ઠેં & & $\tilde{N}$ & $\begin{array}{l}0 \\
-1 \\
-1\end{array}$ & $\begin{array}{l}m \\
\infty^{-}\end{array}$ & $\stackrel{L}{m}$ & $\stackrel{N}{N}$ & $\vec{i}$ & $\hat{m}$ & $\begin{array}{l}\infty \\
\infty^{-}\end{array}$ & $\hat{m}$ & $\tilde{N}$ & $\stackrel{\infty}{-i}$ & $\begin{array}{l}0 \\
m\end{array}$ & $\hat{0}$ & ž & $\mid \begin{array}{l}\tau \\
\dot{\sigma}\end{array}$ & $\begin{array}{l}0 \\
-i\end{array}$ & $\tilde{m}^{n}$ & $\begin{array}{l}0 \\
\dot{*}\end{array}$ & F) \\
\hline & ర్ & & $\begin{array}{l}n \\
-1\end{array}$ & 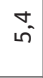 & $\stackrel{2}{r}$ & $\hat{\mathrm{F}}$ & $\stackrel{m}{m}$ & $\stackrel{0}{i}$ & $\stackrel{0}{0}$ & $\begin{array}{l}\hat{y} \\
\tilde{y}\end{array}$ & $\stackrel{m}{\stackrel{m}{*}}$ & $\stackrel{+}{*}$ & $\stackrel{\text { i }}{\text { in }}$ & $\hat{i}$ & $\begin{array}{l}a \\
0\end{array}$ & $\begin{array}{l}-1 \\
0\end{array}$ & $\begin{array}{l}\infty \\
\text { nf }^{\circ}\end{array}$ & $\begin{array}{c}m \\
-i\end{array}$ & $\stackrel{\sim}{\sim}$ & $\begin{array}{l}0 \\
\text { in }\end{array}$ & $\stackrel{m}{m}$ \\
\hline \multirow{6}{*}{ 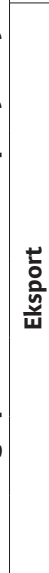 } & & 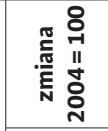 & $\begin{array}{l}-1 \\
\vec{v}\end{array}$ & $\begin{array}{l}n \\
\infty \\
\omega \\
0\end{array}$ & $\hat{\tilde{f}}$ & $\begin{array}{l}\sigma \\
\hat{\sigma} \\
\tilde{m}\end{array}$ & $\begin{array}{l}\infty \\
0^{-} \\
\sim \\
\sim\end{array}$ & $\begin{array}{l}\infty \\
\stackrel{n}{\Omega} \\
\end{array}$ & 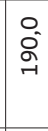 & $\begin{array}{l}\hat{n} \\
\stackrel{2}{\sim}\end{array}$ & $\stackrel{m}{\stackrel{m}{n}}$ & $\begin{array}{l}0 \\
\text { O } \\
\text { N }\end{array}$ & $\begin{array}{l}0 \\
-\vec{y} \\
\dot{y}\end{array}$ & \begin{tabular}{|c|}
$a$ \\
$\tilde{\omega}$ \\
$\infty$ \\
$\sim$
\end{tabular} & \begin{tabular}{|l|}
0 \\
i \\
$m$ \\
$m$
\end{tabular} & $\stackrel{m}{f}$ & $\begin{array}{c}0 \\
0 \\
\infty \\
\infty \\
\infty\end{array}$ & \begin{tabular}{|c|}
$m$ \\
ò \\
ñ
\end{tabular} & 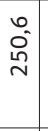 & 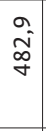 & 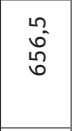 \\
\hline & जิ & 的施 & 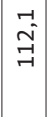 & $\begin{array}{l}m \\
0 \\
0 \\
0 \\
n\end{array}$ & $\begin{array}{l}a \\
\infty \\
0 \\
0 \\
\\
-1\end{array}$ & $\begin{array}{l}0 \\
0 \\
0 \\
0 \\
N\end{array}$ & $\begin{array}{l}a \\
\infty^{2} \\
\tilde{m}^{2}\end{array}$ & $\begin{array}{l}\stackrel{N}{-} \\
\underset{f}{-}\end{array}$ & 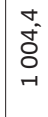 & $\begin{array}{c}\infty \\
\hat{n} \\
- \\
-1 \\
-1\end{array}$ & 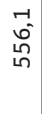 & J & $\begin{array}{l}\infty \\
\emptyset^{-} \\
p^{2}\end{array}$ & $\mid \begin{array}{l}-1 \\
0 \\
0 \\
m\end{array}$ & $\hat{i}$ & $\stackrel{\infty}{\infty}$ & $\begin{array}{l}\vec{\sigma} \\
\sigma \\
\sigma \\
\sigma\end{array}$ & $\mid \begin{array}{l}-1 \\
0 \\
0 \\
0 \\
-1\end{array}$ & 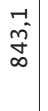 & $\begin{array}{l}n \\
0 \\
0 \\
n \\
n \\
-1\end{array}$ & $\begin{array}{l}\overrightarrow{1} \\
\text { - } \\
\text { ñ } \\
\text { N }\end{array}$ \\
\hline & 党 & \multirow{4}{*}{$\begin{array}{l}\stackrel{0}{0} \\
\frac{3}{\pi} \\
\frac{\pi}{N} \\
\frac{0}{3}\end{array}$} & $0_{0}^{\circ}$ & $\stackrel{-}{-1}$ & in & $\begin{array}{l}a \\
\infty\end{array}$ & O & $\stackrel{n}{0}$ & $\stackrel{\vec{m}}{\vec{m}}$ & $\begin{array}{l}\hat{\sigma} \\
\hat{m}\end{array}$ & $\stackrel{a}{\vec{r}}$ & $\stackrel{\sim}{m}$ & & $\begin{array}{c}m \\
\rightarrow\end{array}$ & $\begin{array}{l}-1 \\
0\end{array}$ & : & $\stackrel{n}{\rightarrow}$ & $\begin{array}{c}m \\
n^{2}\end{array}$ & $\begin{array}{l}\infty \\
\sim \\
\sim\end{array}$ & $\begin{array}{c}m \\
n^{n}\end{array}$ & $\stackrel{n}{\infty}$ \\
\hline & ํㅜㅁ & & $\begin{array}{l}0 \\
0\end{array}$ & $\begin{array}{l}\infty \\
0 \\
\sigma^{-}\end{array}$ & ${ }_{i n}^{m}$ & $\stackrel{\Delta}{\sim}$ & $\underset{-i}{0}$ & $\stackrel{n}{0}$ & $\stackrel{\infty}{m}$ & $\stackrel{\sim}{\sim}$ & $\stackrel{+}{i}$ & $\begin{array}{l}0 \\
\stackrel{\sigma}{*}\end{array}$ & $\stackrel{-}{\circ}$ & $\begin{array}{l}0 \\
i\end{array}$ & $\begin{array}{l}7 \\
0\end{array}$ & O & $\stackrel{\sim}{i}$ & î́ & $\begin{array}{l}0 \\
i \\
i\end{array}$ & of & $\underset{\infty}{+}$ \\
\hline & ઠેे & & $\stackrel{m}{i}$ & $\begin{array}{l}\Delta \\
\dot{J} \\
\vec{J}\end{array}$ & ₹ & $\begin{array}{l}m \\
\sigma^{2}\end{array}$ & 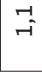 & ò & $\stackrel{+}{i}$ & $\hat{n^{\prime}}$ & $\stackrel{\infty}{\infty}$ & $\hat{m}$ & 악 & $\stackrel{n}{\sim}$ & ra & : & $\stackrel{m}{i}$ & in & $\hat{i}$ & $\begin{array}{l}0 \\
\dot{*}\end{array}$ & o. \\
\hline & రి & & $\stackrel{N}{\sim}$ & $\begin{array}{l}a \\
\vec{f}\end{array}$ & 으 & $\begin{array}{l}0 \\
0 \\
0\end{array}$ & $\hat{F}$ & $\stackrel{N}{-}$ & $\underset{\infty}{N}$ & $\begin{array}{c}m \\
\infty^{\prime}\end{array}$ & $\stackrel{-1}{=}$ & $\hat{0}$ & $ت$ & $\vec{i}$ & $\begin{array}{l}-1 \\
0\end{array}$ & $\vec{c}$ & $\begin{array}{l}\infty \\
0^{-}\end{array}$ & $\mid \begin{array}{l}0 \\
\stackrel{+}{*}\end{array}$ & $\tilde{n}^{n}$ & $\begin{array}{l}0 \\
\text { in }\end{array}$ & हे \\
\hline & \multirow[t]{2}{*}{ 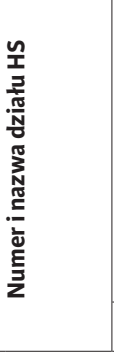 } & 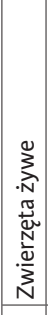 & 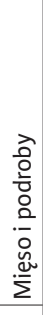 & 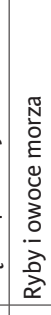 & 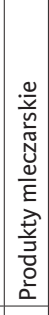 & 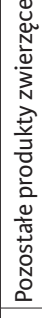 & 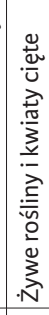 & $\begin{array}{l}\frac{\pi}{3} \\
\frac{N}{\pi} \\
3 \\
3\end{array}$ & 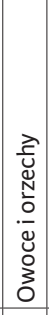 & 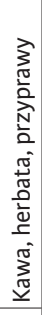 & $\begin{array}{l}. \mathbb{N} \\
\stackrel{0}{N} \\
\stackrel{N}{N}\end{array}$ & 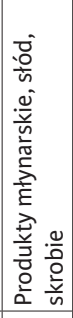 & 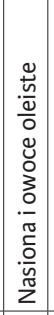 & 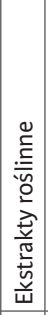 & 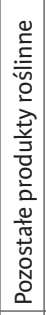 & 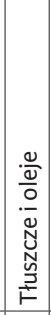 & 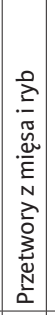 & 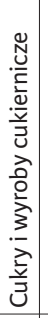 & 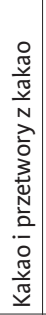 & 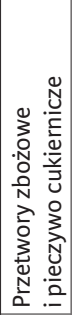 \\
\hline & & & -1 & $N$ & $m$ & $\nabla$ & 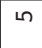 & 6 & $\wedge$ & $\infty$ & $a$ & 어 & $\vec{F}$ & $\approx$ & $m$ & $\underset{\sim}{\triangleleft}$ & 号 & $\begin{array}{ll}0 \\
-1\end{array}$ & $\neg$ & $\begin{array}{l}\infty \\
\sim \\
-1\end{array}$ & ने \\
\hline
\end{tabular}




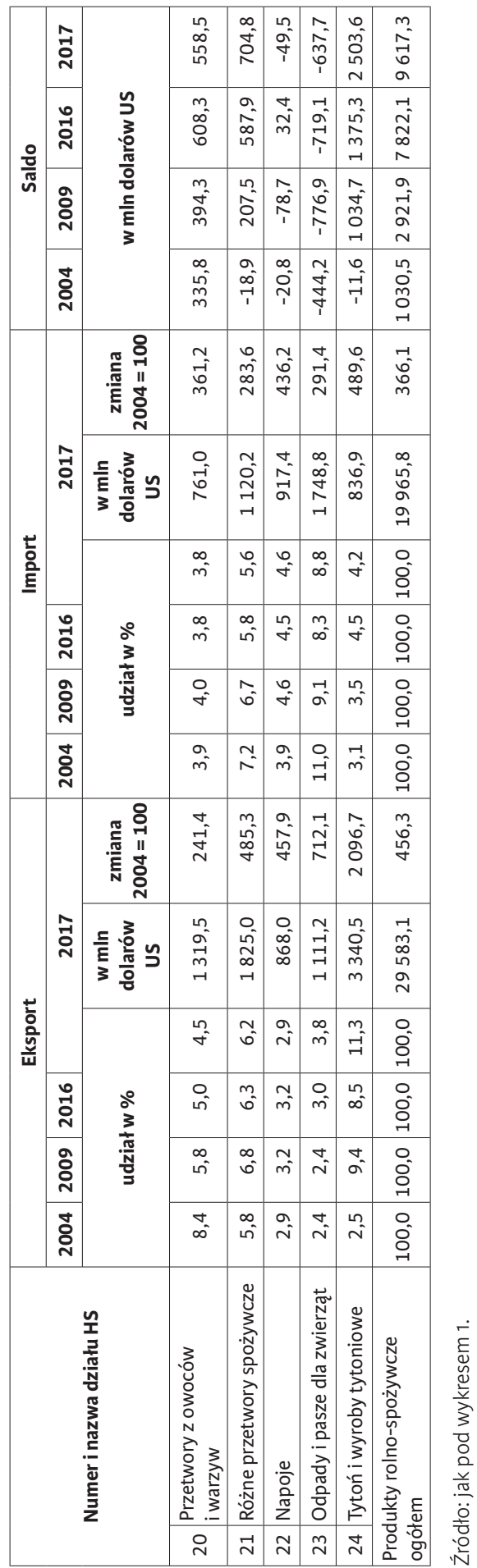


Wskaźnik ujawnionych przewag komparatywnych w eksporcie według B. Balassy określa następująca formuła ${ }^{46}$ :

$$
R C A_{i k}=\frac{X_{i k}}{\sum_{i=1}^{N} X_{i k}}: \frac{X_{i w}}{\sum_{i=1}^{N} X_{i w}}
$$

gdzie:

$R C A_{i k}$ - wskaźnik ujawnionych przewag komparatywnych w eksporcie grupy produktów $i$ przez kraj $k$ na określonym rynku,

$X_{i k}$ - eksport grupy produktów $i$ przez kraj $k$ na określony rynek,

$X_{i w}$ - eksport grupy produktów $i$ przez grupę krajów $w$ na określony rynek,

$N$ - liczba grup produktów.

Wskaźnik RCA przybiera wartości od zera do nieskończoności, przy czym wyróżnia się dwa przedziały o odmiennych interpretacjach. Gdy wskaźnik ten przyjmuje wartości większe od 1 (udział danej grupy towarów w eksporcie omawianego kraju jest wyższy od odpowiedniego udziału w światowym eksporcie), badany kraj ma ujawnione przewagi komparatywne w eksporcie na określony rynek. W przeciwnym razie, gdy wskaźnik przyjmuje wartości mniejsze od 1 (udział danej grupy towarów w eksporcie omawianego kraju jest niższy niż udział tej grupy towarów w światowym eksporcie), badany kraj nie ma ujawnionych przewag komparatywnych w eksporcie na określony rynek. O posiadaniu czy braku ujawnionych przewag komparatywnych będzie zatem decydować to, czy udział danego produktu w eksporcie analizowanego kraju na wybrany rynek jest wyższy czy niższy niż odpowiedni udział tego produktu w eksporcie wszystkich państw świata na ten rynek.

Szerokie zastosowanie wskaźnika RCA, jako miernika konkurencyjności, wynika z jego prostej formuly, która w sposób naturalny daje odpowiedź na pytanie, w jakich grupach towarowych dany kraj ma przewagi komparatywne ${ }^{47}$. Ponadto w literaturze zwraca się uwagę na niewielką wrażliwość formuły tego wskaźnika na różnice w fazach cyklu koniunkturalnego między poszczególnymi krajami $^{48}$.

\section{Wskaźniki TC i RCA w polskim handlu rolno-spożywczym ogółem}

W 2004 r. wartość obu mierników pozycji konkurencyjnej w polskim handlu rolno-spożywczym wskazywała na istnienie przewagi konkurencyjnej polskich

46 B. Balassa, Trade Liberalization and Revealed Comparative Advantage, „The Manchester School" 1965, Vol. 33, s. 99-123.

47 Ł. Ambroziak, I. Szczepaniak, Monitoring i ocena konkurencyjności polskich producentów żywności (4). Pozycja konkurencyjna, seria „Program Wieloletni 2011-2014”, nr 74, IERiGŻ-PIB, Warszawa 2013, s. 44-45.

48 J.C. Hartigan, The U.S. tariff and comparative advantage: A survey of method, „Weltwirtschaftliches Archiv” 1981, Vol. 117(1), s. 65-109. 
producentów żywności na rynku światowym $(\mathrm{TC}=118,9 \%$; RCA $=1,24)$. Polska miała nadwyżkę w handlu produktami rolno-spożywczymi - wartość eksportu tych produktów była wyższa od wartości ich importu o prawie 19\%. Ponadto polscy producenci żywności mieli ujawnione przewagi komparatywne w eksporcie rolno-spożywczym na rynek światowy. Udział produktów rolno-spożywczych w całkowitym eksporcie Polski był wyższy o 24\% niż udział tych produktów w światowym eksporcie (wykres 2).

Wykres 2. Wskaźniki pozycji konkurencyjnej w polskim handlu produktami rolno-spożywczymi

160,0 1,70

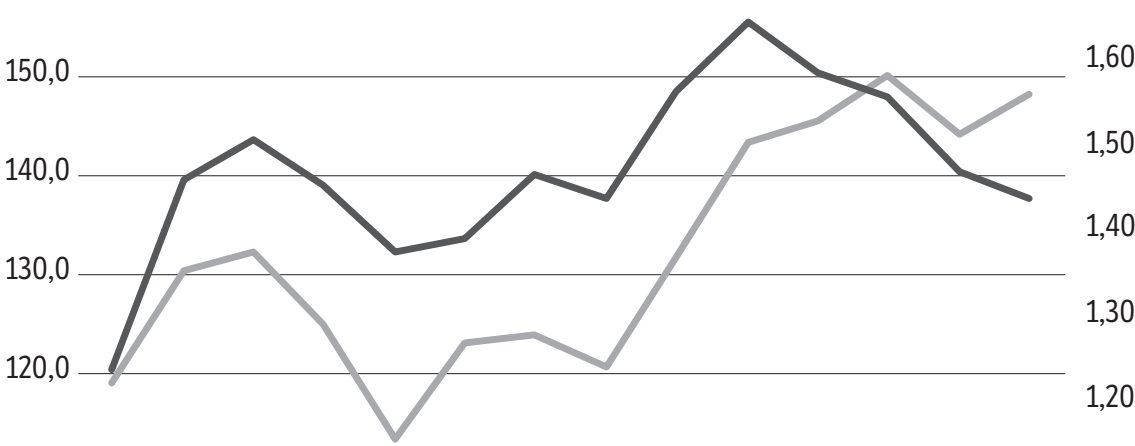

110,0

20042005200620072008200920102011201220132014201520162017

— Wskaźnik pokrycia importu eksportem (TC) - oś lewa (w\%)

— Wskaźnik ujawnionych przewag komparatywnych B. Balassy (RCA) - oś prawa

Źródło: jak pod wykresem 1.

Początkowo pozycja konkurencyjna polskich producentów żywności na rynku światowym poprawiała się, co wynikało z uzyskania w 2004 r. dostępu do dużego wspólnego rynku UE. Jednakże już w latach 2007-2008 wartości obu mierników konkurencyjności wyraźnie się pogorszyły. W 2008 r. wskaźnik pokrycia importu eksportem był nawet niższy niż w roku akcesji. Począwszy od 2009 r. ponownie obserwowana była poprawa pozycji konkurencyjnej polskich producentów i eksporterów żywności. Z pewnymi wahaniami wskaźnik TC wzrastał do 2015 r., po czym ponownie nieznacznie się obniżył. W 2017 r. odnotowano kolejny jego wzrost. Wartość eksportu rolno-spożywczego była wyższa od wartości importu o ponad 48\%, a wskaźnik TC zwiększył się o 29,3 pkt proc. w porównaniu z rokiem 2004. Z kolei wskaźnik RCA wzrastał do 
2013 r., kiedy to jego wartość wyniosła 1,65, a następnie systematycznie malał. W 2017 r. udział produktów rolno-spożywczych w eksporcie Polski był o 44\% wyższy niż ich udział w eksporcie światowym. W porównaniu z rokiem 2004 oznacza to wzrost wartości wskaźnika RCA o 0,20 pkt.

\section{Wskaźniki TC w polskim handlu rolno-spożywczym według grup produktów}

W 2004 r. spośród 24 działów HS obejmujących produkty rolno-spożywcze Polska miała nadwyżkę w handlu produktami dziesięciu działów (tabela 4). Najwyższe wskaźniki pokrycia importu eksportem (TC > 300\%) odnotowano $\mathrm{w}$ takich grupach produktów, jak: produkty mleczarskie $(\mathrm{TC}=781 \%)$, przetwory z mięsa i ryb $(\mathrm{TC}=432 \%)$ oraz zwierzęta żywe $(\mathrm{TC}=332 \%)$. Wysokie (TC $>200 \%$ ) były także wskaźniki TC $\mathrm{w}$ handlu cukrami i wyrobami cukierniczymi, warzywami, mięsem i podrobami jadalnymi, przetworami z warzyw i owoców oraz przetworami zbożowymi i pieczywem cukierniczym. Ponadto nadwyżkę osiągnięto także $\mathrm{w}$ handlu pozostałymi produktami roślinnymi oraz kakao i przetworami z kakao. W przypadku czternastu grup produktów Polska miała w 2004 r. deficyt. Najniższe wskaźniki TC (poniżej 30\%) odnotowano w takich grupach, jak: ekstrakty roślinne, tłuszcze i oleje, zboża oraz odpady i pasze dla zwierząt.

Spośród grup produktów, w handlu którymi notowano nadwyżkę w 2004 r., nadwyżkę tę udało się utrzymać w 2017 r. w ośmiu grupach (wykres 3). Przy

Wykres 3. Wskaźniki TC w handlu rolno-spożywczym Polski, według działów HS (w \%)

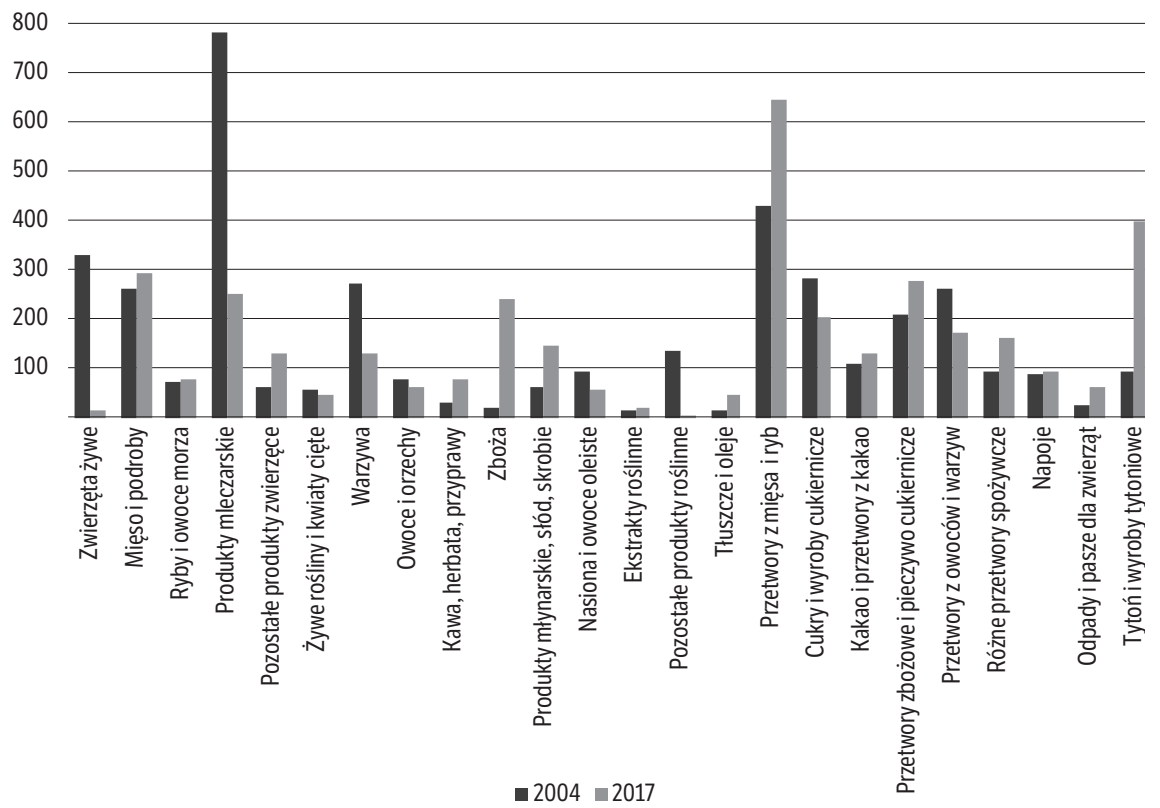

Źródło: jak pod wykresem 1. 


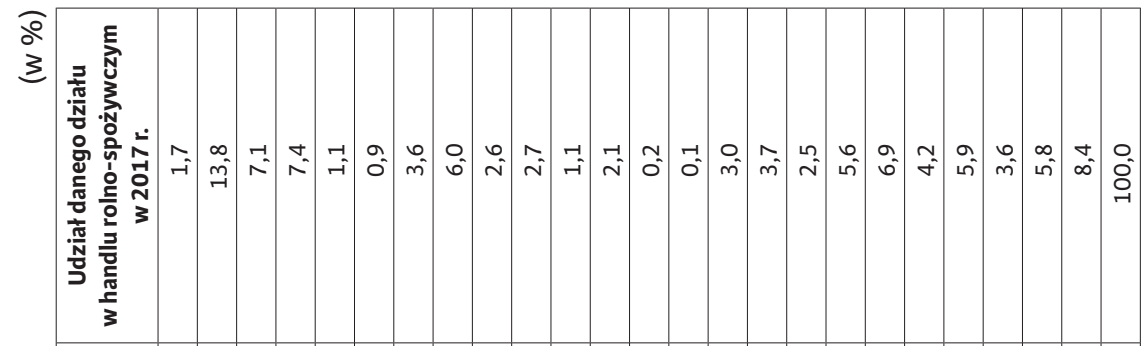

今ิ

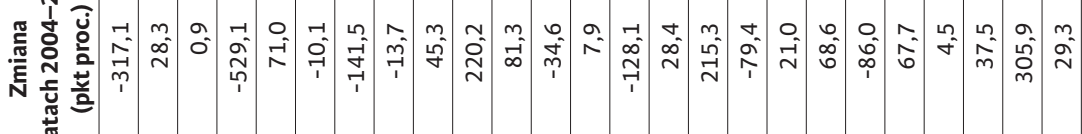

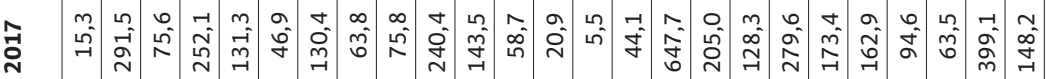

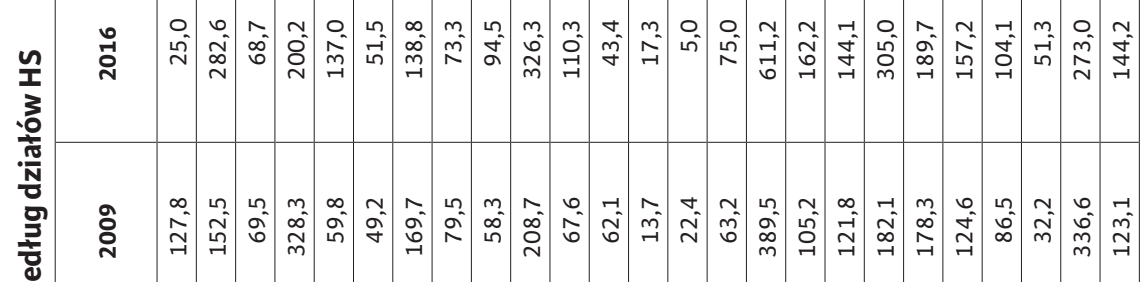

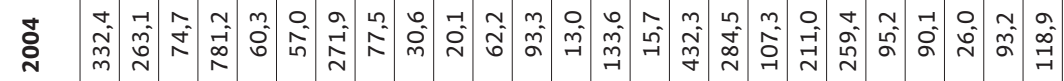

'̃ 
tym w czterech z nich wskaźniki TC wzrosły (przetwory z mięsa i ryb, przetwory zbożowe i pieczywo cukiernicze, mięso i podroby jadalne oraz kakao i przetwory z kakao), a w czterech - zmalały (produkty mleczarskie, warzywa, przetwory z warzyw i owoców oraz cukry i wyroby cukiernicze). Nie udało się natomiast Polsce utrzymać nadwyżki w handlu zwierzętami żywymi oraz pozostałymi produktami roślinnymi. W okresie członkostwa w UE Polska uzyskała natomiast nadwyżkę $\mathrm{w}$ handlu pięcioma innymi grupami produktów. Były to: tytoń i wyroby tytoniowe, zboża, produkty młynarskie, słód i skrobie, różne przetwory spożywcze oraz pozostałe produkty zwierzęce.

W 2017 r. Polska miała nadwyżkę w handlu trzynastoma (z 24) grupami produktów (tabela 4). Najwyższe wskaźniki TC (powyżej 250\%) odnotowano $\mathrm{w}$ takich grupach, jak: przetwory z mięsa i ryb $(\mathrm{TC}=648 \%)$, tytoń $\mathrm{i}$ wyroby tytoniowe $(\mathrm{TC}=399 \%)$, mięso i podroby jadalne $(\mathrm{TC}=292 \%)$, przetwory zbożowe i pieczywo cukiernicze $(\mathrm{TC}=280 \%)$ oraz produkty mleczarskie $(\mathrm{TC}=252 \%)$. Wysokie (powyżej 150\%) wskaźniki TC cechowały również handel zbożami, cukrami i wyrobami cukierniczymi, przetworami z warzyw i owoców oraz różnymi przetworami spożywczymi. Relatywnie najmniejsza nadwyżka (TC poniżej 150\%) była natomiast notowana w takich grupach, jak: kakao i przetwory z kakao, produkty młynarskie, słód i skrobie, pozostałe produkty zwierzęce oraz warzywa. Z kolei deficyt obrotów handlowych odnotowano w jedenastu grupach produktów, wyodrębnionych według działów HS. Były to: pozostałe produkty roślinne, zwierzęta żywe, ekstrakty roślinne, tłuszcze i oleje, żywe rośliny i kwiaty cięte (TC $<50 \%)$, a także nasiona i owoce oleiste, owoce, odpady i pasze dla zwierząt, ryby i owoce morza oraz kawa, herbata i przyprawy $(50<\mathrm{TC}<80)$ oraz napoje (95\%).

\section{Wskaźniki RCA w polskim handlu rolno-spożywczym według grup produktów}

W 2004 r. spośród 24 działów HS obejmujących produkty rolno-spożywcze polscy producenci i eksporterzy żywności mieli ujawnione przewagi komparatywne w eksporcie na rynek światowy produktów z czternastu grup (tabela 5). Najwyższe wskaźniki RCA odnotowano w eksporcie zwierząt żywych (RCA $=3,04)$. Oznacza to, że udział tych zwierząt w polskim eksporcie na rynek światowy był ponadtrzykrotnie wyższy niż ich udział w światowym eksporcie. Silne ujawnione przewagi komparatywne (RCA > 2,00) odnotowano także w przypadku eksportu takich grup produktów, jak: pozostałe produkty zwierzęce, przetwory z warzyw i owoców, warzywa, cukry i wyroby cukiernicze, produkty mleczarskie oraz kakao i przetwory z kakao. Konkurencyjne na rynku światowym były również polskie: przetwory zbożowe i pieczywo cukiernicze, różne przetwory spożywcze, mięso i podroby, przetwory z mięsa i ryb, owoce i orzechy, pozostałe produkty roślinne oraz produkty młynarskie, słód i skrobie. Ujawnionych przewag komparatywnych polscy producenci nie mieli natomiast $\mathrm{w}$ eksporcie dziesięciu grup produktów. 
Wykres 4. Wskaźniki RCA w handlu rolno-spożywczym Polski, według działów HS (w \%)

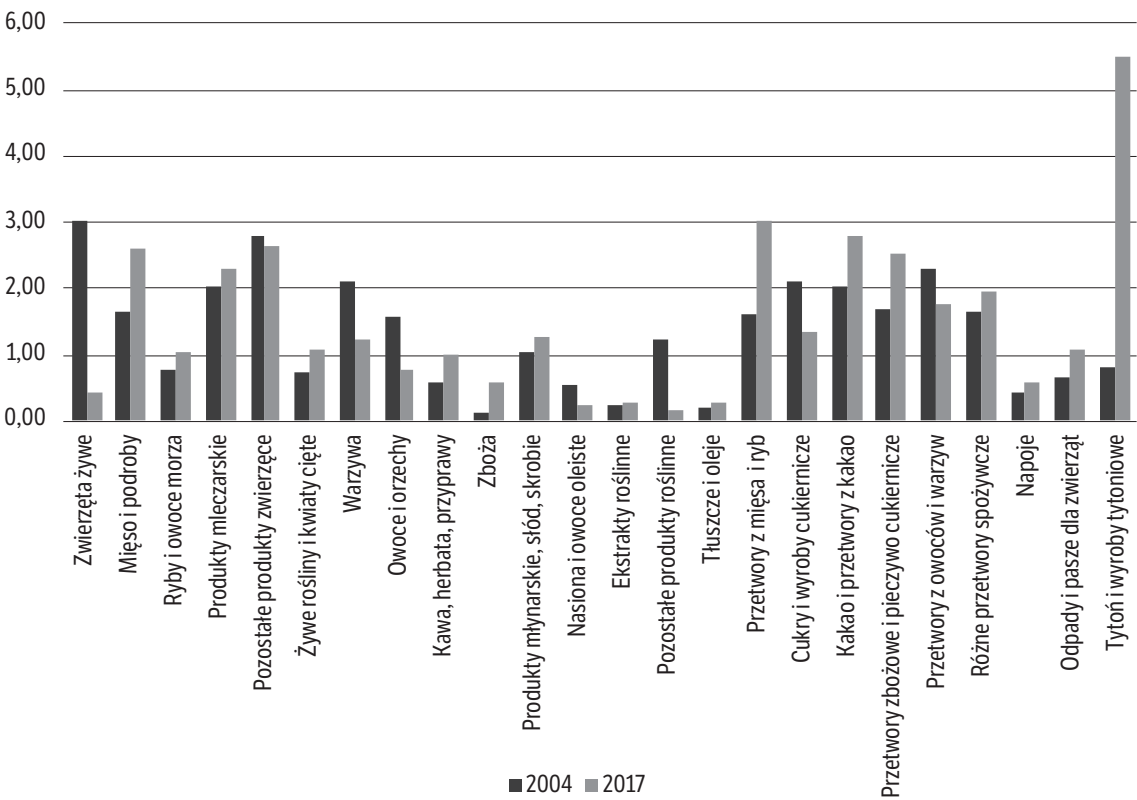

Źródło: jaki pod wykresem 1.

Wśród czternastu grup produktów, w których eksporcie polscy producenci mieli w 2004 r. ujawnione przewagi komparatywne, takie przewagi udało się utrzymać w 2017 r. w jedenastu grupach (wykres 4). W eksporcie pozostałych produktów zwierzęcych, warzyw, przetworów z warzyw i owoców oraz cukrów i wyrobów cukierniczych wskaźniki RCA zmalały. W siedmiu działach wskaźniki te wzrosły. W latach 2004-2017 pozycja polskich producentów żywności najbardziej umocniła się w eksporcie przetworów z mięsa i ryb (wzrost wskaźnika RCA o 1,40 pkt), mięsa i podrobów jadalnych (o 0,96 pkt), przetworów zbożowych i pieczywa cukierniczego (o 0,83 pkt) oraz kakao i przetworów z kakao (o 0,78 pkt). Relatywnie najmniej wskaźniki RCA wzrosły w grupie różnych przetworów spożywczych, produktów mleczarskich oraz produktów młynarskich, słodu i skrobi. Polscy producenci żywności nie zdołali w okresie członkostwa w UE utrzymać posiadanych w 2004 r. ujawnionych przewag komparatywnych w eksporcie zwierząt żywych, owoców i orzechów oraz pozostałych produktów roślinnych. W kilku grupach produktów wzrost wskaźników RCA w latach 2004-2017 był jednak na tyle duży, że udało się Polsce uzyskać takie przewagi na rynku światowym. Dotyczyło to ryb i owoców morza, żywych roślin i ciętych kwiatów, kawy, herbaty i przypraw, odpadów i pasz dla zwierząt, a przede wszystkim tytoniu i wyrobów tytoniowych. 


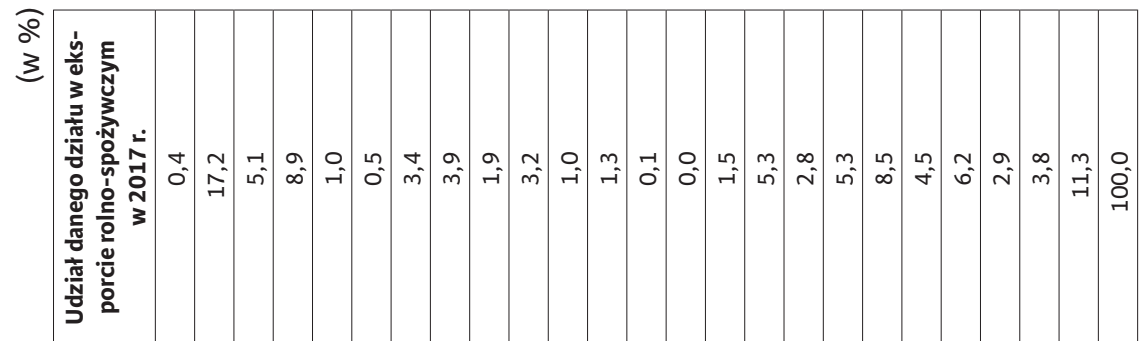

$\hat{\mathrm{i}}$

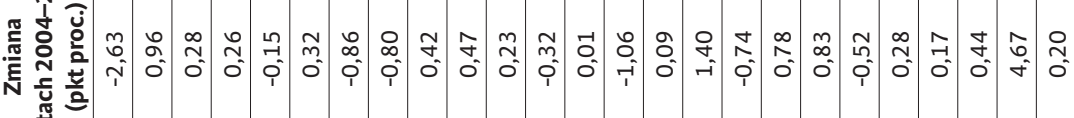
究

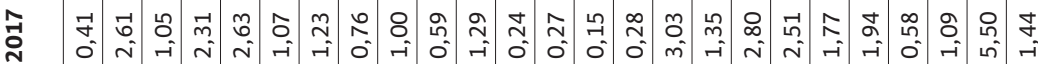

논

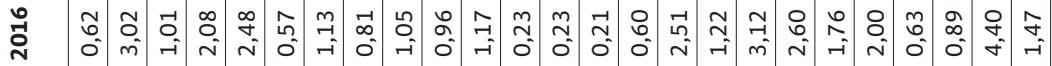

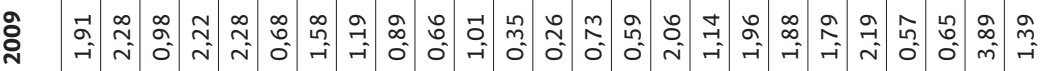

$\frac{i \overline{\frac{u}{0}}}{0}$

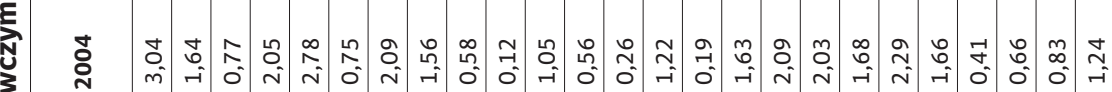

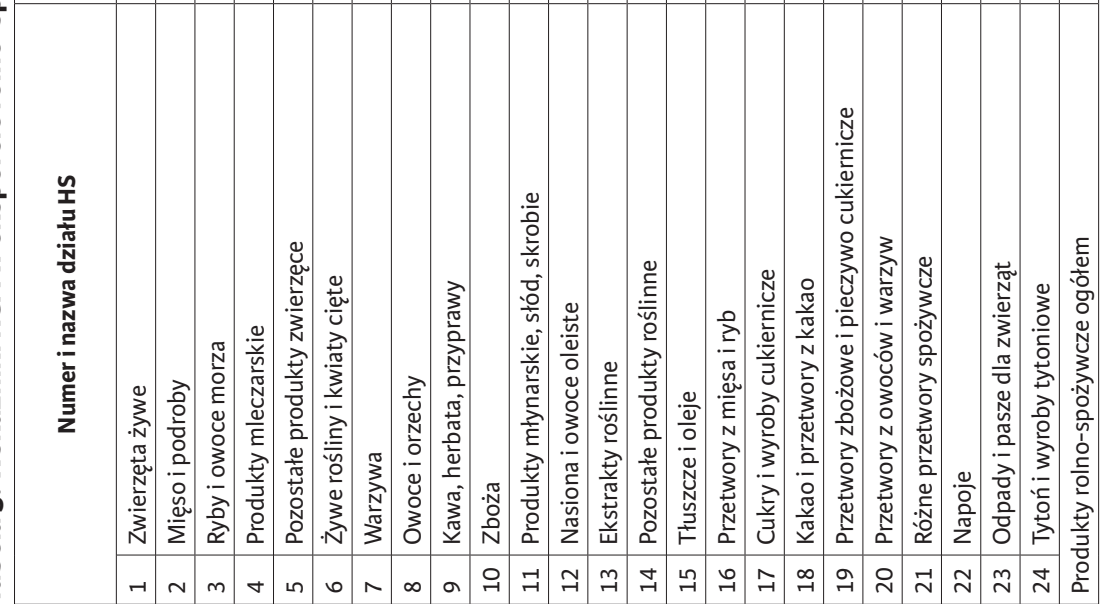


W 2017 r. Polska miała ujawnione przewagi komparatywne w eksporcie na rynek światowy szesnastu (z 24) grup produktów według działów HS (tabela 5). Najwyższe wskaźniki RCA odnotowano w eksporcie tytoniu i wyrobów tytoniowych oraz przetworów $\mathrm{z}$ mięsa i ryb (odpowiednio $\mathrm{RCA}=5,50$ oraz RCA $=3,03$ ). Oznacza to, że udział tytoniu i wyrobów tytoniowych oraz przetworów z mięsa i ryb w polskim eksporcie ogółem był odpowiednio pięcioipółkrotnie i trzykrotnie wyższy niż udział tych produktów w światowym eksporcie. Silną pozycję konkurencyjną na rynku światowym $(\mathrm{RCA}>2,00)$ mieli również polscy producenci kakao i przetworów z kakao, pozostałych produktów zwierzęcych, mięsa i podrobów, przetworów zbożowych i pieczywa cukierniczego oraz produktów mleczarskich. Wysokie wskaźniki RCA (powyżej 1,50) mieli także eksporterzy różnych przetworów spożywczych oraz przetworów z warzyw i owoców. Relatywnie najmniej konkurencyjne na rynku światowym były natomiast: cukry i wyroby cukiernicze, produkty młynarskie, słód i skrobie, warzywa, odpady i pasze dla zwierząt, żywe rośliny i kwiaty cięte, ryby i owoce morza oraz kawa, herbata i przyprawy.

W ośmiu grupach produktów (z 24) Polska nie miała w 2017 r. ujawnionych przewag komparatywnych w eksporcie na rynek światowy. W trzech grupach takie przewagi utraciła w okresie członkostwa w UE. Były to wspomniane już zwierzęta żywe, owoce i orzechy oraz pozostałe produkty roślinne. W kolejnych pięciu grupach przewag komparatywnych polscy producenci żywności nie mieli w całym analizowanym okresie. Dotyczyło to zbóż, nasion i owoców oleistych, ekstraktów roślinnych, tłuszczów i olejów oraz napojów.

\section{Ocena pozycji konkurencyjnej Polski w handlu produktami rolno- spożywczymi na podstawie wskaźników TC i RCA według grup produktów}

Konkurencyjność polskiego handlu zagranicznego produktami rolno-spożywczymi (wg działów HS) mierzona łącznie wskaźnikiem pokrycia importu eksportem (TC) oraz wskaźnikiem ujawnionych przewag komparatywnych w eksporcie B. Balassy (RCA) ukazuje bardzo zróżnicowaną sytuację w przekroju produktów (tabela 6). Według oceny na podstawie obu tych wskaźników w 2017 r. konkurencyjne (TC > 100\% i RCA > 1,00) były następujące grupy produktów: mięso i podroby, produkty mleczarskie, pozostałe produkty zwierzęce, warzywa, produkty młynarskie, słód i skrobie, przetwory z mięsa i ryb, cukry i wyroby cukiernicze, kakao i przetwory z kakao, przetwory zbożowe i pieczywo cukiernicze, przetwory z owoców i warzyw, różne przetwory spożywcze oraz tytoń i wyroby tytoniowe. Polska nie była natomiast konkurencyjna (TC $<100 \%$ i RCA $<1,00)$ w eksporcie: zwierząt żywych, owoców i orzechów, nasion i owoców oleistych, ekstraktów roślinnych, pozostałych produktów roślinnych, tłuszczów i olejów oraz napojów. Handel pozostałymi grupami produktów był konkurencyjny tylko przy ocenie na podstawie jednego z wyżej wymienionych wskaźników, tj. wskaźnika TC (zboża) lub RCA (ryby i owoce 
morza, żywe rośliny i kwiaty cięte, kawa, herbata, przyprawy, odpady i pasze dla zwierząt), a zatem nie była możliwa jednoznaczna ocena konkurencyjności.

W 2017 r. udział wymienionych dwunastu działów HS, które na podstawie zarówno wskaźnika TC, jak i RCA uznać można za konkurencyjne, w eksporcie rolno-spożywczym Polski wyniósł 75,4\%, podczas gdy niekonkurencyjnych siedmiu działów - tylko 10,1\%. Dla porównania w 2004 r., zarówno konkurencyjnych, jak i niekonkurencyjnych działów HS było po dziesięć, a ich udział w eksporcie rolno-spożywczym Polski sięgał odpowiednio 64,4\% i 18,8\%. Spośród dziesięciu konkurencyjnych grup produktów w 2004 r. osiem utrzymało swoją pozycję (mięso i podroby, produkty mleczarskie, warzywa, przetwory z mięsa i ryb, cukry i wyroby cukiernicze, kakao i przetwory z kakao, przetwory zbożowe i pieczywo cukiernicze, przetwory z owoców i warzyw), a dwie ją straciły (zwierzęta żywe oraz pozostałe produkty roślinne). W latach 2004-2017 do konkurencyjnych działów HS dołączyły: pozostałe produkty zwierzęce, produkty młynarskie, słód i skrobie, różne przetwory spożywcze oraz tytoń i wyroby tytoniowe.

Tabela 6. Produkty rolno-spożywcze (działy HS) według wartości wskaźnika RCA i wskaźnika TC w 2017 r.

\begin{tabular}{|c|c|c|c|}
\hline & \multicolumn{2}{|c|}{ Wskaźnik RCA } \\
\hline & & powyżej 1,00 & poniżej 1,00 \\
\hline \multirow[t]{2}{*}{ 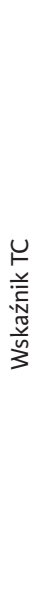 } & 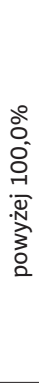 & $\begin{array}{l}\text { Mięso i podroby (02) } \\
\text { Produkty mleczarskie (04) } \\
\text { Pozostałe produkty zwierzęce (05) } \\
\text { Warzywa (07) } \\
\text { Produkty młynarskie, słód, skrobie (11) } \\
\text { Przetwory z mięsa i ryb (16) } \\
\text { Cukry i wyroby cukiernicze (17) } \\
\text { Kakao i przetwory z kakao (18) } \\
\text { Przetwory zbożowe i pieczywo cukiernicze (19) } \\
\text { Przetwory z owoców i warzyw (20) } \\
\text { Różne przetwory spożywcze (21) } \\
\text { Tytoń i wyroby tytoniowe (24) }\end{array}$ & Zboża (10) \\
\hline & 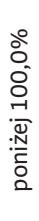 & $\begin{array}{l}\text { Ryby i owoce morza (03) } \\
\text { Żywe rośliny i kwiaty cięte (06) } \\
\text { Kawa, herbata, przyprawy (09) } \\
\text { Odpady i pasze dla zwierząt (23) }\end{array}$ & $\begin{array}{l}\text { Zwierzęta żywe (01) } \\
\text { Owoce i orzechy (08) } \\
\text { Nasiona i owoce oleiste (12) } \\
\text { Ekstrakty roślinne (13) } \\
\text { Pozostałe produkty roślinne (14) } \\
\text { Tłuszcze i oleje (15) } \\
\text { Napoje (22) }\end{array}$ \\
\hline
\end{tabular}

Źródło: jak pod wykresem 1.

Pozytywne zmiany, jakie dokonały się w analizowanym okresie w handlu rolno-spożywczym Polski, polegały zatem przede wszystkim na zwiększeniu liczby działów, których produkty są konkurencyjne i z powodzeniem sprzedają się na rynku światowym, a co za tym idzie na wzroście udziału w eksporcie (do poziomu ok. 75\%) produktów, które uznać można na podstawie stosowanych wskaźników za konkurencyjne na tym rynku. 


\section{Podsumowanie i wnioski}

Dynamiczny rozwój wymiany handlowej produktami rolno-spożywczymi oraz wzrost wskazań poszczególnych wskaźników mierzących pozycję konkurencyjną Polski w handlu zagranicznym na rynku światowym wskazują na wyraźną poprawę międzynarodowej konkurencyjności polskich producentów żywności. Polski sektor rolno-spożywczy należy obecnie do najbardziej konkurencyjnych sektorów polskiej gospodarki. Poprawie i wzmacnianiu konkurencyjności polskich producentów żywności sprzyjały odpowiednie przekształcenia w sektorze, rozpoczęte już w pierwszych latach transformacji systemowej, nasilone w okresie przygotowań do członkostwa w UE, a następnie stymulowane procesami pogłębiającej się integracji gospodarczej i handlowej z państwami członkowskimi UE. Po przystąpieniu do UE polska gospodarka żywnościowa objęta została wsparciem finansowym zarówno z funduszy strukturalnych UE, jak i budżetu WPR, co pozwoliło na przyspieszenie procesów modernizacji. Najważniejszym źródłem wzrostu wielkości i wartości polskiego eksportu rolno-spożywczego pozostawał dostęp do rynku wewnętrznego UE. Ekspansji polskiego eksportu rolno-spożywczego sprzyjał również rosnący popyt na żywność ze strony rynków krajów rozwijających się i gospodarek wschodzących. Dzięki rozbudowanej sieci porozumień i powiązań handlowych UE ze światem Polska uzyskała dostęp do nowych rynków zbytu i wyraźnie wzmocniła swoją pozycję w międzynarodowym handlu rolno-spożywczym. Pozytywnie na konkurencyjność polskich producentów żywności wpływały również uwarunkowania krajowe - wysoka dynamika wzrostu gospodarczego, utrzymująca się stabilność makroekonomiczna oraz stosunkowo niskie koszty pracy, pozwalające na uzyskiwanie przewag cenowych nad konkurentami.

Międzynarodowa konkurencyjność polskiego sektora rolno-spożywczego w analizowanym okresie była wysoka. Perspektywy jej utrzymania w kolejnych latach mogą już nie być takie pewne. Wiele wskazuje na to, że rola niektórych czynników, które jeszcze niedawno pozytywnie oddziaływały na osiągane wyniki handlowe i pozycję konkurencyjną, będzie stopniowo się zmniejszać. W związku z niekorzystnymi zmianami demograficznymi w Europie w kolejnych latach i dekadach możliwości ekspansji i zwiększania sprzedaży na rynku wewnętrznym UE będą się kurczyć. Problemem pozostaje również kryzys wielostronnego systemu handlowego WTO, który sprzyja wzmacnianiu polityk nakierowanych na protekcjonizm rolny i odgradzanie się od konkurencji. Niepewne są zatem perspektywy uzyskania i utrzymania dostępu do rynków zbytu, na których oczekiwane są największe wzrosty popytu na żywność. Niekorzystne dla polskiej gospodarki żywnościowej będzie też wystąpienie Wielkiej Brytanii z UE, prawdopodobnie skutkujące ograniczeniami w handlu i zmianami w finansowaniu polityk unijnych. Zmiany te, w połączeniu ze spodziewanym wyczerpywaniem się przewag cenowo-kosztowych, mogą negatywnie wpływać na konkurencyjność polskiego eksportu rolno-spożywczego i w rezultacie na konkurencyjność całego sektora. 


\section{Bibliografia}

2018 European Semester. Country Report Poland, European Commission, Brussels, 7.3.2018 SWD(2018) 219 final.

Ambroziak Ł., Szczepaniak I., Monitoring i ocena konkurencyjności polskich producentów żywności (4). Pozycja konkurencyjna, seria „Program Wieloletni 2011-2014”, nr 74, IERiGŻ-PIB, Warszawa 2013.

Ambroziak Ł., Szczepaniak I., Ryzyko kursowe a handel zagraniczny produktami rolno-spożywczymi Polski [w:] Ryzyko w gospodarce żywnościowej - teoria i praktyka, red. J. Góral, M. Wigier, seria „Monografie Programu Wieloletniego 2015-2019”, nr 48, IERiGŻ-PIB, Warszawa 2017.

Balassa B., Trade Liberalization and Revealed Comparative Advantage, „The Manchester School" 1965, Vol. 33.

Beckman J., Dyck J., Heerman K.E.R., The Global Landscape of Agricultural Trade, 1995-2014, EIB-181, U.S. Department of Agriculture, Economic Research Service, November 2017.

Bodirsky B.L. i in., Global Food Demand Scenarios for the $21^{\text {st }}$ Century, „PLOS ONE” 2015, nr 10(11), https://doi.org/10.1371/journal.pone.0139201.

Gstöhl S., De Bièvre D., The Trade Policy of the European Union, Palgrave, London 2018, https://doi.org/10.1057/978-1-349-93583-3.

Hartigan J.C., The U.S. tariff and comparative advantage: A survey of method, „Weltwirtschaftliches Archiv” 1981, Vol. 117(1).

Impacts of EU trade agreements on the agricultural sector, report prepared for the European Commission, Directorate-General for Agriculture and Rural Development, by A/S Copenhagen Economics, December 2016, https://ec.europa.eu/agriculture/sites/agriculture/files/external-studies/2016-bilateral-trade-agreements/final-report_en.pdf. Industrial Structure Statistics 1994, OECD, Paris 1996 [za:] M.J. Stankiewicz, Konkurencyjność przedsiębiorstwa. Budowanie konkurencyjności przedsiębiorstwa w warunkach globalizacji, Wydawnictwo TNOiK „Dom Organizatora”, Toruń 2005.

Kosior K., Wpływ uwarunkowań makroekonomicznych, politycznych i społecznych na konkurencyjność sektora żywnościowego w Polsce w kontekście procesów globalnych [w:] Konkurencyjność polskich producentów żywności i jej determinanty (3), red. I. Szczepaniak, seria „Monografie Programu Wieloletniego 2015-2019”, nr 67, IERiGŻ-PIB, Warszawa 2017, https://doi.org/10.30858/pw/9788376587097.1.

Kosior K., Ambroziak Ł., Brexit - potential implications for the Polish food sector [w:] The Common Agricultural Policy of the European Union - the present and the future. EU Member States point of view, red. M. Wigier, A. Kowalski, seria „Monographs of Multi-annual Programme 2015-2019”, No. 73.1, IAFE-NRI, Warsaw 2018, https:// doi.org/10.30858/pw/9788376587431.13.

Kowalski A., Niespodziewany sukces przemystu spożywczego, „Gazeta Bankowa” z 16 grudnia 2017 r., http://wgospodarce.pl/informacje/44004-niespodziewany-sukces-przemyslu-spozywczego. 
Mikuła A., Demograficzne uwarunkowania światowego i krajowego popytu na żywność w latach 2000-2015 [w:] Ewolucja światowego i krajowego popytu na żywność w kontekście zmian demograficznych i bezpieczeństwa żywnościowego, red. K. Świetlik, seria „Monografie Programu Wieloletniego 2015-2019”, nr 65, IERiGŻ-PIB, Warszawa 2017.

Misala J., Międzynarodowa konkurencyjność gospodarki narodowej, PWE, Warszawa 2011.

Misala J., Międzynarodowa zdolność konkurencyjna i międzynarodowa konkurencyjność gospodarki narodowej. Podstawy teoretyczne, Politechnika Radomska, Radom 2007.

Olczyk M., Konkurencyjność. Teoria i praktyka, CeDeWu.PL, Warszawa 2008.

Overview of FTA and other trade negotiations, European Commission, updated May 2018, http://trade.ec.europa.eu/doclib/docs/2006/december/tradoc_118238.pdf.

Pawlak K., Międzynarodowa zdolność konkurencyjna sektora rolno-spożywczego krajów Unii Europejskiej, seria „Rozprawy Naukowe. Uniwersytet Przyrodniczy w Poznaniu", nr 448, Poznań 2013.

Pawlak K., Poczta W., Międzynarodowy handel rolny, PWE, Warszawa 2011.

Peneder M., Competitiveness and industrial policy: from rationalities of failure towards the ability to evolve, „Cambridge Journal of Economics” 2017, Vol. 41, No. 3, https:// doi.org/10.1093/cje/bew025.

Siudek T., Drabarczyk K., Teoretyczne i aplikacyjne aspekty konkurencyjności-przegląd literatury, „Zeszyty Naukowe Szkoły Głównej Gospodarstwa Wiejskiego. Ekonomika i Organizacja Gospodarki Żywnościowej” 2015, nr 112, https://doi.org/10.22630/ eiogz.2015.112.54.

Stankiewicz M.J., Konkurencyjność przedsiębiorstwa. Budowanie konkurencyjności przedsiębiorstwa w warunkach globalizacji, Wydawnictwo TNOiK „Dom Organizatora”, Toruń 2005.

Szczepaniak I., Przewagi komparatywne w polskim handlu produktami rolno-spożywczymi [w:] Konkurencyjność polskich producentów żywności i jej determinanty (3), red. I. Szczepaniak, seria „Monografie Programu Wieloletniego 2015-2019”, nr 67, IERiGŻ-PIB, Warszawa 2017, https://doi.org/10.30858/pw/9788376587097.2.

Szczepaniak I., System „konkurencyjnośc” - wybrane aspekty teoretyczne i empiryczne [w:] Monitoring i ocena konkurencyjności polskich producentów żywności (5) Synteza, red. I. Szczepaniak, seria „Program Wieloletni 2010-2014”, nr 115, IERiGŻ-PIB, Warszawa 2014.

Szczepaniak I., Uwarunkowania zewnętrzne konkurencyjności polskich producentów żywności [w:] Konkurencyjność polskich producentów żywności i jej determinanty (1), red. I. Szczepaniak, seria „Monografie Programu Wieloletniego 2015-2019”, nr 11, IERiGŻ-PIB, Warszawa 2015.

The competitive position of the European food and drink industry, Final Report, ECSIP Consortium, Publications Office of the European Union,Luxembourg 2016.

The Future of Food and Agriculture. Trends and Challenges, Food and Agriculture Organization of the United Nations, Rome 2017. 
Wigier M., Pomoc publiczna dla polskiego sektora żywnościowego [w:] Przemysł spożywczy - makrootoczenie, inwestycje, ekspansja zagraniczna, red. I. Szczepaniak, K. Firlej, Uniwersytet Ekonomiczny w Krakowie, IERiGŻ-PIB, Kraków-Warszawa 2015.

World Population Prospects. The 2015 Revision. Key Findings and Advance Tables, United Nations, New York 2015.

Zahniser S., Beckman J., Heerman K.E.R., World Agricultural Trade Experiences Sizable Growth but Still Faces Barriers, International Markets \& U.S. Trade, February 05, 2018.

\section{Bazy danych}

Eurostat, Annual National Accounts, Prices, Population and Social Conditions, http:// ec.europa.eu/eurostat/data/database/ oraz Hourly labour costs, April 2018.

GUS, Bank Danych Makroekonomicznych, https://bdm.stat.gov.pl oraz https://stat.gov. $\mathrm{pl}$ / wskazniki-makroekonomiczne.

Komisja Europejska, http://ec.europa.eu/budget/figures/index_en.cfm.

OECD, Labour productivity and utilization, https://data.oecd.org/lprdty/labour-productivity-and-utilisation.htm; https://data.oecd.org/lprdty/gdp-per-hour-worked. htm.

WITS-Comtrade, The World Integrated Trade Solution, Comtrade database, https:// wits.worldbank.org. 